Article

\title{
Selection of Hyperspectral Vegetation Indices for Monitoring Yield and Physiological Response in Sweet Maize under Different Water and Nitrogen Availability
}

\author{
Mohamed Houssemeddine Sellami 1,2 $\mathbb{D}$, Rossella Albrizio 1,*(D), Milica Čolović 3,4,*, Mohamad Hamze ${ }^{4,5}$ (D), \\ Vito Cantore ${ }^{6}$ (D), Mladen Todorovic ${ }^{4}$ (D) , Lea Piscitelli ${ }^{4}$ (D) and Anna Maria Stellacci ${ }^{3}$ (D)
}

1 Institute for Agricultural and Forestry Systems in the Mediterranean (ISAFOM), National Research Council (CNR), Piazzale Enrico Fermi 1, 80055 Napoli, Italy; mohamed.sellami@isafom.cnr.it

2 Interdepartmental Research Centre on the "Earth Critical Zone", University of Naples Federico II, 80055 Napoli, Italy

3 Department of Soil, Plant and Food Sciences, University of Bari Aldo Moro, 70126 Bari, Italy; annamaria.stellacci@uniba.it

4 CIHEAM-Mediterranean Agronomic Institute of Bari (CIHEAM-IAMB), 70010 Bari, Italy; mohamad.hamze@inrae.fr (M.H.); mladen@iamb.it (M.T.); piscitelli@iamb.it (L.P.)

5 CIRAD, CNRS, INRAE, TETIS, University of Montpellier, AgroParisTech, CEDEX 5, 34093 Montpellier, France

6 Institute of Sciences of Food Production (ISPA), National Research Council (CNR), Via Amendola, 122/O, 70125 Bari, Italy; vito.cantore@ispa.cnr.it

* Correspondence: rossella.albrizio@cnr.it (R.A.); milica.colovic@uniba.it (M.Č.)

Citation: Sellami, M.H.; Albrizio, R.; Čolović, M.; Hamze, M.; Cantore, V.; Todorovic, M.; Piscitelli, L.; Stellacci, A.M. Selection of Hyperspectral Vegetation Indices for Monitoring Yield and Physiological Response in Sweet Maize under Different Water and Nitrogen Availability. Agronomy 2022, 12, 489. https://doi.org/ 10.3390/agronomy12020489

Academic Editor: Saseendran S. Anapalli

Received: 3 January 2022

Accepted: 12 February 2022

Published: 16 February 2022

Publisher's Note: MDPI stays neutral with regard to jurisdictional claims in published maps and institutional affiliations.

Copyright: (C) 2022 by the authors. Licensee MDPI, Basel, Switzerland. This article is an open access article distributed under the terms and conditions of the Creative Commons Attribution (CC BY) license (https:// creativecommons.org/licenses/by/ $4.0 /)$.

\begin{abstract}
This study used hyperspectral reflectance data to evaluate the crop physiological parameters of sweet maize. Principal component analysis (PCA) was applied to identify the wavelengths that primarily contributed to each selected PC. Correlation analysis and multiple linear regression, with a stepwise algorithm, were used to select the best-performing vegetation indices (VIs) for monitoring the yield and physiological response of sweet maize grown under different water and nitrogen availability. The spectral reflectance measurements of crops were taken during the mid-season stage, for two consecutive growing seasons. The multivariate regression results showed that red-edge group indices, such as CARI (Chlorophyll Absorption Reflectance Index), DD (Double Difference Index), REIP (Red-Edge Inflection Point), and Clred-edge (Chlorophyll Red-Edge) indices were good predictors of yield and physiological parameters, confirming the crucial role of the red-edge spectral region that also emerged through PCA. Moreover, DD, REIP, and Clred-edge VIs were able to discriminate transient temporary stress at the mid-season stage, as well as to separate water and $\mathrm{N}$ stress levels. Therefore, hyperspectral reflectance VIs can provide valid information to growers, helping them identify and discriminate between different stress conditions.
\end{abstract}

Keywords: hyperspectral proximal sensing; principal component analysis (PCA); multiple linear regression (MLR); variable selection; water and nitrogen deficiency

\section{Introduction}

Water and nitrogen $(\mathrm{N})$ represent two major limiting factors for maize production [1]. Water stress acts directly on growth and development, photosynthesis, dry mass production; in addition yield [2] might be severely diminished, especially if water deficiency is prolonged [3]. Nitrogen is considered the most crucial nutrient for proper growth and development, as it is the principal regulator of many physiological and biochemical processes, and is strongly linked to chlorophyll content [4-6] and quantity of yield [1]. Matching $\mathrm{N}$ supply to water availability, both spatially and temporally, is essential to accomplish optimal crop response, offering opportunities for precision agriculture [7]. In recent years, proximal and remote sensing methods have been widely used as effective tools for precision agriculture, as they allow rapid, non-destructive monitoring of growth, along with both 
water and nutrient stress [8]. These methods can be efficiently utilized to measure vegetation's spectral reflectance, which is related to biophysical and biochemical components (such as chlorophyll, nitrogen content, dry mass production, and water status) [9-13].

There are numerous biophysical, physiological, and biochemical crop parameters that can be monitored using spectral reflectance data generated by remote/proximal sensing techniques. Timely observation of plant biophysical properties and eco-physiological status, such as leaf area, chlorophyll, and nitrogen contents, have become critical to diagnose plant responses to environmental stress [14,15].

All environmental stresses, such as water deficit, salinity, and nutrient deficiency, evoke a similar plant response, as they tend to decrease leaf area, and numerous stresses cause stomatal closure. As a result, diagnosing or monitoring the impact of a specific stress based on a single observed response is frequently challenging [16].

The use of spectral signatures can reveal not only the pigment composition of the leaves, but also the leaf area, and even the canopy's water content. In this case, stress responses can be detected and quantified using any or all of these spectral signature properties. However, many of the proposed spectral indices are rather limited in their applicability, because they were developed using empirical regression techniques for one specific experiment and cannot be easily extrapolated to other situations [16]. Hence, any spectral index should be thoroughly validated for the specific site conditions [16].

Crops under optimal growing conditions have a very high reflectance in the nearinfrared region (NIR, 760-900 nm), high in the green (520-600 nm), and low in blue $(450-520 \mathrm{~nm})$ and red $(630-690 \mathrm{~nm})$ spectra [17], where they absorb almost all of the incident light. Under stress conditions, plants change their absorption of incident light in the visible and NIR ranges [18,19]. Therefore, the variation of reflectance in the green and far-red $(690-720 \mathrm{~nm})$ spectra provides a particularly standard pigment-related response, and provides reliable indications of stress conditions [20].

Field spectroradiometers can generate a continuous spectrum for any object [1] because of their ability to collect spectral signatures in narrow $(<10 \mathrm{~nm})$ and contiguous wavelengths in the visible and near-infrared region; thus, they represent effective tools to estimate crop status [21], as well as morpho-physiological [22] and biochemical plant traits at different phenological stages [23].

However, weak spectral information, caused by crop structure characteristics and soil background conditions [19], as well as information redundancy due to the high degree of correlation of hundreds of neighboring wavebands [24], poses a challenge in terms of data analysis and interpretation [25]. For this reason, data pre-processing and analysis are essential to extract crucial information from raw spectral data and estimate crop status efficiently.

The main approaches used to analyze hyperspectral data of vegetation are focused on the computation of vegetation indices (VIs), and on exploring the whole reflectance spectrum through multivariate statistical analysis methods. The analysis of the whole spectrum is usually aimed at identifying the narrow bands (optimal bands) able to capture most of the information on crops properties $[17,23,26]$. However, it can also be focused on extracting derived variables or factors capable of summarizing spectral information and predicting crop behavior. Principal component analysis (PCA) is the most-applied method among multivariate approaches. PCA is an unsupervised dimensionality-reduction method that is often used to reduce the dimensionality of the multivariate data set, while holding most of the variation within the data $[25,27]$. Several studies on the investigation of hyperspectral plant response showed the effectiveness of PCA in coping with multicollinearity problems occurring along many wavelengths [24], and selecting important wavelengths crucial for discriminating the effects of $\mathrm{N}$ availability $[17,23,28]$, water regimes [29], and plant diseases [30].

Computation of VIs is among the most studied and widespread methods for crop status estimation from spectral reflectance data [31]. The most traditional VIs are those using broadband wavelengths. Among them, the most used are the Normalized Difference 
Vegetation Index (NDVI, [32]), which is strictly associated with variation of both leaf area index (LAI) and fractional vegetation cover, and all its alternatives, including the Soil Adjusted Vegetation Index (SAVI, [33]), the Optimized Soil Adjusted Vegetation Index (OSAVI, [34]), and the Enhanced Vegetation Index (EVI, [35]). The last ones (SAVI, OSAVI and EVI) have been used to overcome the main constraints given by the disturbance of soil or background reflectance. The Green Normalized Difference Vegetation Index (GNDVI, [36]) is related to the fraction of active photosynthetic radiation intercepted by crops [37].

All these indices have an intrinsic aggregated nature; this results in an evident loss of spectral information, which is available when analyzing narrow spectral bands [38].

When moving from broad band toward hyperspectral sensors, more indices can be calculated; in the last four decades, many VIs, acquired by both ground and remote sensing, have been published [39]. Recently, Morcillo-Pallarés et al. [31] classified VIs on the basis of their sensitivity towards (i) LAI, (ii) leaf chlorophyll content, and (iii) leaf water content. The broadband VIs belong mainly to the first group, strongly correlated to LAI modifications and senescence. In the second category are VIs such as the Transformed Chlorophyll Absorption in Reflectance Index (TCARI, [40]), the Clgreen and Clred-edge chlorophyll indices [41,42], chlorophyll red-edge [43], the double difference index (DD), and the doublepeak index (DPI, [44]). The red-edge position has been found to have an excellent correlation to chlorophyll content, and it is obtained by the point of maximum slope between the red chlorophyll absorption region and the region of high NIR reflectance [45]. The shape and position of the red edge are affected by chlorophyll content modifications, which are always strictly linked to change in leaves structure, and thus strongly influenced by variation in the water and nitrogen status of vegetation [44]. In the third group are VIs classified as water indices, such as the Water Band Index (WBI) and the Normalized Water Index [46]. These indices use the reflectance-based NIR region at $950 \pm 20 \mathrm{~nm}$, where there is a water absorption band and a reference wavelength reflectance at $900 \mathrm{~nm}$. The ratio of these reflectance values can offer a powerful opportunity to assess the water status of vegetation [47].

Many VIs are designed for a diverse array of applications and research purposes, and often the similarity of acquired information requires the use of rigorous approaches to select the most informative and sensitive indicators for assessing plant status and the onset of stress conditions. Correlation analysis and multiple linear regression (MLR), through a stepwise algorithm, are commonly employed for this purpose.

MLR is a statistical technique that uses several explanatory variables to predict the outcome of a response variable. The goal of MLR is to model the linear relationship between the spectral reflectance bands and crop characteristics [48]. MLR can be used not only to establish relationships between spectral VIs and investigated crop characteristics, but also to select the most informative variables for the estimation of crop properties [23]. Previously published studies have reported MLR as a widely used method for rapidly estimating crop leaf $\mathrm{N}$ concentration [49,50] and grain yield [51,52]. In detail, Gracia-Romero et al. [53] used correlation analysis and MLR with a forward stepwise method to compare the capability of ground-based and aerially assessed VIs in predicting grain yield and leaf phosphorous content in maize. Kefauver et al. [52] applied a stepwise selection algorithm to compare the capacity of the field and UAV-based RGB and multispectral indices to differentiate the nitrogen-related performance in barley.

In this study, the sensitivity of spectral information, derived by both analysis of the whole spectrum and the computation of VIs, was investigated to describe the physiological and yield response of sweet maize under different water and nitrogen management. To this aim, the factors extracted through PCA and selected VIs were analyzed using correlation analysis and MLR with a stepwise algorithm. In the following sections their performance is assessed and discussed. 


\section{Materials and Methods}

\subsection{Study Area}

Two-year research was conducted at the experimental field of the Mediterranean Agronomic Institute of Bari (IAMB) in Valenzano $\left(41^{\circ} 03^{\prime} \mathrm{N}, 16^{\circ} 53^{\prime} \mathrm{E}, 77 \mathrm{~m}\right.$ above sea level). The experimental site is characterized by typical Mediterranean climate conditions, with mild winters and hot, dry summers. The average annual precipitation is about $550 \mathrm{~mm}$ (30 years average), distributed mostly during autumn and winter. The average monthly air temperature ranges from $8{ }^{\circ} \mathrm{C}$ in January to $24^{\circ} \mathrm{C}$ in July and August. The soil of the study area is silty-clay-loam [54]. Meteorological data were obtained from the weather station next to the experimental field.

Sweet maize (Zea mays var. saccharata L., hybrid Centurion F1) was cultivated in the 2019 and 2020 growing seasons in rows $0.5 \mathrm{~m}$ apart, with a distance between plants in the row of $0.2 \mathrm{~m}$ and a plant density of 10 plants per square meter.

The crop was grown under three water regimes (WR) in combination with two N levels. Water regimes were: (i) full irrigation $\left(\mathrm{I}_{100}\right)$, (ii) deficit irrigation $\left(\mathrm{I}_{50}\right)$, and (iii) rainfed treatment $\left(\mathrm{I}_{0}\right)$. Deficit irrigation was obtained by applying $50 \%$ of the irrigation requirements, while rainfed treatment was watered only once, immediately after sowing. $\mathrm{N}$ levels were: (i) $50 \mathrm{~kg} \mathrm{ha}^{-1}$ (low level -LN) and (ii) $300 \mathrm{~kg} \mathrm{ha}^{-1}$ (high level-HN).

Treatments were arranged in a split-plot experimental design, with three replicates, with water regime as main-plot factor and $\mathrm{N}$ as sub-plot, sized $10 \times 10 \mathrm{~m}$.

Irrigation was performed by surface drip method, using a drip line for each row and drippers $\left(2.2 \mathrm{~L} \mathrm{~h}^{-1}\right)$ spaced $0.20 \mathrm{~m}$ apart. Crop water balance and irrigation scheduling were managed using an Excel-based model [55] that estimates day by day crop evapotranspiration and irrigation water requirements through the standard procedure proposed by the FAO 56 document [56]. As reported by Piscitelli et al. [57], 8 and 12 irrigations were applied in the first and second year, respectively, with the corresponding seasonal irrigation amounts equal to 281 and $291 \mathrm{~mm}$ in $\mathrm{I}_{100}$ treatment. Half of these amounts were applied in I50 treatments.

In both years and before sowing, fertilizers were applied to the total cropping surface as follows: $\mathrm{N}, 50 \mathrm{~kg} \mathrm{ha}^{-1}$ as urea $(46 \%$ of $\mathrm{N})$; phosphorus $\left(\mathrm{P}_{2} \mathrm{O}_{5}\right), 100 \mathrm{~kg} \mathrm{ha}^{-1}$ as pyrophosphate $\left(20 \% \mathrm{P}_{2} \mathrm{O}_{5}\right)$; and potassium $\left(\mathrm{K}_{2} \mathrm{O}\right), 200 \mathrm{~kg} \mathrm{ha}^{-1}$ as potassium sulfate $\left(51 \% \mathrm{~K}_{2} \mathrm{O}\right)$. At sixth-leaf stage, $\mathrm{N} 250 \mathrm{~kg} \mathrm{ha}^{-1}$, as urea, was supplied to the HN treatment.

\subsection{Measurements}

Leaf gas exchanges, leaf chlorophyll content, and vegetation reflectance measurements were taken at about one week intervals, 5 times in 2019 (from end of June to end of July) and 4 times in 2020 (from mid-July to mid-August), all of them within the mid-season stage. All measurements were acquired on clear sunny days around 11:00-13:00 h (solar time).

\subsubsection{Leaf Gas Exchange}

Net photosynthetic $\mathrm{CO}_{2}$ assimilation rate $\left(\mathrm{A}, \mu \mathrm{mol} \mathrm{m} \mathrm{m}^{-2} \mathrm{~s}^{-1}\right)$, stomatal conductance (gs, mol m $\left.{ }^{-2} \mathrm{~s}^{-1}\right)$, and leaf transpiration $\left(\mathrm{Tr}, \mathrm{mmol} \mathrm{m}^{-2} \mathrm{~s}^{-1}\right)$ were measured using a portable open-system gas-exchange analyzer (Li-6400XT (Li-Cor Biosciences, Lincoln, NE, USA)) provided by an external bottled $\mathrm{CO}_{2}$ source supplying $400 \mu \mathrm{mol} \mathrm{mol}{ }^{-1} \mathrm{CO}_{2}$ concentration inside the leaf chamber. The instrument software calculated the various gas-exchange parameters on the basis of the von Caemmerer and Farquhar [58] model. Intrinsic water use efficiency (WUEi, $\mu \mathrm{mol} \mathrm{mol}{ }^{-1}$ ) was calculated as the ratio of net photosynthetic rate to stomatal conductance. Measurements were taken on intact, healthy, green, and well exposed leaves, over a clipped leaf surface of $6.0 \mathrm{~cm}^{2}$. Each measurement was replicated three times per plot.

\subsubsection{Leaf Chlorophyll Content}

The Chlorophyll Content Index (CCI) of leaves was indirectly measured by means of an optical meter (SPAD-502, Konica Minolta, Osaka, Japan) on 25 replicates per plot. 


\subsubsection{Plant Reflectance}

Plant reflectance was measured by using a high spectral resolution ASD FieldSpec Hand-Held 2 spectro-radiometer (Analytical Spectral Devices, Inc., Boulder, CO, USA). This instrument measures reflectance with a wavelength range of 325-1075 nm, an accuracy of $\pm 1 \mathrm{~nm}$, and a resolution of $<3 \mathrm{~nm}$ at $700 \mathrm{~nm}$. The field of view (FOV) of the bare fiber-optic probe was $25^{\circ}$. The spectrum of a white $\left(\mathrm{BaSO}_{4}\right)$ reference panel with known reflectance properties was acquired to derive the reflectance of the target.

Measurements were acquired on three plants for each plot. The vegetation spectrum was measured from a distance of $10 \mathrm{~cm}$ above the crop, with a spot size of approximately $14 \mathrm{~cm}^{2}$. Gradually, as maize grew and expanded, the distance from the vegetation increased to $60 \mathrm{~cm}$. Thereafter, data were processed by means of View Spec software.

The reflectance data were restricted to the 395-1004 nm interval, which was considered noise-free. Then, statistical analyses were performed. The reflectance measurements were averaged over $10 \mathrm{~nm}$ to reduce collinearity and overfitting [59]. In this way, 61 derived reflectance variables were obtained; the name of the variables indicated the central wavelength. The spectral indices used in this study were computed from narrow bands reflectance measurements and are reported in Table 1.

\subsubsection{Fresh Grain Yield}

Harvesting was completed on 9 August and on 3 September in the first and in the second years, respectively, when grain reached about $30 \%$ in dry matter, by sampling $2 \mathrm{~m}^{2}$ in the middle of each plot. Total weight of the ears was determined after the removal of the bracts. Fresh grain yield is reported in the text as GY.

\subsubsection{Agronomic Water Productivity}

Agronomic Water Productivity (WP) was calculated as the ratio of fresh grain yield to the total amount of water supplied (irrigation and rainfall) and expressed as $\mathrm{kg} \mathrm{m}^{-3}$.

\subsubsection{Plant Nitrogen Uptake}

At maturity, 10 plants per plot were harvested and the fresh weight was measured for the determination of total biomass. The dry plant was ground, and aliquots were weighted in tubes for digestion prior to total $\mathrm{N}$ determination trough the Kjeldhal method. Plant nitrogen uptake (NUptake) was calculated as the product of $\mathrm{N}$ percentage by dry weight.

\subsection{Statistical Analysis}

Dependent variables-fresh grain yield (GY), agronomic water productivity (WP), and nitrogen uptake (NUptake)—were preliminarily evaluated for normal distribution and homogeneity of variance according to the Kolmogorov-Smirnov test and Bartlett's test, respectively. Since the normality assumption was violated, factorial nonparametric analysis of variance for mixed designs was used by applying the Aligned Rank Transform analysis. Analysis of variance from the $3 \times 2$ factorial experiment in a split plot design was then conducted, and significance of differences was tested using Fisher's Least Significant Difference (LSD) at a 5\% probability level. This analysis was carried out using the software package agricolae [60] and ARTool [61] in R studio software [62]. This package is available via the Comprehensive R Archive Network (CRAN, https: / / cran.r-project.org (accessed on 12 April 2020)).

A multivariate analysis approach was applied to select the optimal spectral bands using XLSTAT 2020 (Addinsoft, New York, NY, USA, [63]). Principal component analysis (PCA) was performed on 61 derived variables from the mid-season stage of each growing season. PCA was carried out on the correlation matrix of 61 variables to obtain a few new components, explaining most of the variation of the initial spectral data. PCA outputs included treatment component scores and variable loadings for each selected component.

The Principal Components (PCs) with eigenvalues greater than one, and cumulatively explaining more than $90 \%$ of the total variance, were selected for the ordination analysis [64]; 
variable loadings were examined to identify the wavelengths that most contributed to each selected component [65]. Within each extracted component, the five bands with the highest loadings (in absolute value) were selected [66].

The Pearson correlation was used to determine the relationship between GY, WP, NUptake, physiological parameters (A, gs, Tr, WUEi, and LCC), vegetation indices, and the components extracted using PCA. This analysis was carried out using the software package Corrplot [67] in R studio software [62].

Table 1. Indices derived from the hyperspectral visible and near infrared wavelengths.

\begin{tabular}{|c|c|c|c|}
\hline Acronym & Indices & Equation & Reference \\
\hline \multicolumn{4}{|c|}{ Broadband Greenness for Structure } \\
\hline NDVI & Normalized Difference Vegetation Index & $(\mathrm{R} 860-\mathrm{R} 650) /(\mathrm{R} 860+\mathrm{R} 650)$ & [68] \\
\hline mNDVI & Modified Normalized Difference Vegetation Index & $(\mathrm{R} 775-\mathrm{R} 670) /(\mathrm{R} 775+\mathrm{R} 670)$ & [69] \\
\hline RDVI & Renormalized Difference Vegetation Index & $(\mathrm{R} 800-\mathrm{R} 670) /\left((\mathrm{R} 800+\mathrm{R} 670)^{0.5}\right)$ & [70] \\
\hline SAVI & Soil Adjusted Vegetation Index & $\begin{array}{c}(\mathrm{R} 860-\mathrm{R} 650) /(\mathrm{R} 860+\mathrm{R} 650+\mathrm{L}) \times \\
(1+\mathrm{L}) \\
\text { Low vegetation, } \mathrm{L}=1, \text { intermediate, } 0.5 \\
\text { and high } 0.25\end{array}$ & [33] \\
\hline GNDVI & Green Normalized Difference Vegetation Index & $(\mathrm{R} 860-\mathrm{R} 550) /(\mathrm{R} 860+\mathrm{R} 550)$ & [36] \\
\hline EVI & Enhanced Vegetation Index & $\begin{array}{c}2.5 \times(\mathrm{R} 860-\mathrm{R} 650) /(\mathrm{R} 860+(6 \times \mathrm{R} 650) \\
-(7.5 \times \mathrm{R} 470)+1)\end{array}$ & [35] \\
\hline OSAVI & Optimized Soil Adjusted Vegetation Index & $(\mathrm{R} 860-\mathrm{R} 650) /(\mathrm{R} 860+\mathrm{R} 650+0.16)$ & [34] \\
\hline \multicolumn{4}{|c|}{ Narrowband Greenness for Chlorophyll, Carotenoids, and Light Use Efficiency } \\
\hline CARI & Chlorophyll Absorption Reflectance Index & {$[(\mathrm{R} 700-\mathrm{R} 670)-0.2 \times(\mathrm{R} 700-\mathrm{R} 550)]$} & [71] \\
\hline MCARI & Modified Chlorophyll Absorption Reflectance Index & $\begin{array}{c}{[(\mathrm{R} 700-\mathrm{R} 670)-0.2 \times(\mathrm{R} 700-\mathrm{R} 550)]} \\
\times(\mathrm{R} 700 / \mathrm{R} 670)\end{array}$ & {$[72]$} \\
\hline TCARI & Transformed Chlorophyll Absorption Reflectance Index & $\begin{array}{c}3 \times[(R 700-R 670)-0.2 \times(R 700- \\
R 550) \times(R 700 / R 670)]\end{array}$ & [73] \\
\hline TCARI/OSAVI & Integrated TCARI and OSAVI & & [73] \\
\hline Clgreen & & $(\mathrm{R} 730 / \mathrm{R} 530)-1$ & [41] \\
\hline Clred-edge & Chlorophyll Indices & $(\mathrm{R} 850 / \mathrm{R} 730)-1$ & [42] \\
\hline CIrededge710 & Chlorophyll Red-Edge & $(\mathrm{R} 750 / \mathrm{R} 710)-1$ & [43] \\
\hline DD & Double Difference Index & $(R 749-R 720)-(R 701-R 672)$ & {$[44]$} \\
\hline DPI & Double Peak Index & $\mathrm{R} 688+\mathrm{R} 710 /(\mathrm{R} 697)^{2}$ & [44] \\
\hline PSRI & Plant Senescence Reflectance Index & $(\mathrm{R} 680-\mathrm{R} 500) / \mathrm{R} 750$ & [74] \\
\hline PRI & Photochemical Reflectance Index & $(\mathrm{R} 531-\mathrm{R} 570) /(\mathrm{R} 531+\mathrm{R} 570)$ & [75] \\
\hline SIPI & Structure Insensitive Pigment Index & $(\mathrm{R} 800-\mathrm{R} 445) /(\mathrm{R} 800-\mathrm{R} 680)$ & {$[76]$} \\
\hline REIP & Red-Edge Inflection Point & $\begin{array}{c}700+40 \times[(((\mathrm{R} 670+\mathrm{R} 780) / 2)- \\
\mathrm{R} 700) /(\mathrm{R} 740-\mathrm{R} 700)]\end{array}$ & [77] \\
\hline NDRE & Normalized Difference Red-Edge & $(\mathrm{R} 790-\mathrm{R} 720) /(\mathrm{R} 790+\mathrm{R} 720)$ & [78] \\
\hline RVSI & Red-Edge Vegetation Stress Index & $(\mathrm{R} 714+\mathrm{R} 752) / 2-\mathrm{R} 733$ & [79] \\
\hline \multicolumn{4}{|c|}{ Canopy Water Content } \\
\hline WBI & Water Band Index & $\mathrm{R} 970 / \mathrm{R} 900$ & [80] \\
\hline NWI1 & & $(\mathrm{R} 970-\mathrm{R} 900) /(\mathrm{R} 970+\mathrm{R} 900)$ & [81] \\
\hline NWI2 & Normalized Water Index & $(\mathrm{R} 970-\mathrm{R} 850) /(\mathrm{R} 970+\mathrm{R} 850)$ & \\
\hline WBI:NDVI & & WBI/NDVI & [47] \\
\hline
\end{tabular}

$\mathrm{R}$ represents the reflectance value at specified wavelengths in $\mathrm{nm}$.

The multiple linear regression using stepwise technique was applied to explain GY, WP, NUptake, and physiological variables variation from VIs across different water supplies and nitrogen treatment on both growing seasons, satisfying the criteria of probability-ofF-to-enter $\leq 0.05$ and probability-to-remove $\geq 0.05$. The overall model's performance was evaluated by its coefficient of determination $\left(R^{2}\right)$, a measure of the proportion of variance in variables estimated that can be predicted by the explanatory variables (VIs). This analysis was carried out using a regression analysis procedure of SAS software (University Edition, SAS Institute, Inc., Cary, NC, USA). 


\section{Results}

\subsection{Agronomic Water Productivity, Nitrogen Uptake and Yield Response}

Table 2 reports the results of the analysis of variance for fresh grain yield (GY), agronomic water productivity (WP), and plant nitrogen uptake (NUptake) for two consecutive growing seasons. The rainfed treatment did not reach reproductive stage because of strong and prolonged drought. The GY of both growing seasons varied significantly in relation to the amount of available water. In 2020, GY increased as a consequence of N fertilization, but in 2019 this increment only showed a trend towards significance $(p=0.08)$. In both seasons, GY was almost the same in the full irrigation treatment, with production of about $15 \mathrm{t} \mathrm{ha}^{-1}$. GY was $72.2 \%$ and $44.9 \%$ less in the $\mathrm{I}_{50}$ treatment for the 2019 and 2020 growing seasons, respectively, compared to the full irrigation treatment. In both years, the interaction between water regime and nitrogen level was not significant for GY.

WP was strongly affected by $\mathrm{N}$ level in both growing seasons. By increasing water supply from $\mathrm{I}_{50}$ to $\mathrm{I}_{100}$, WP increased more than double in 2019 and no significant change was observed in 2020. Under high amount of $\mathrm{N}$, as average of $\mathrm{I}_{50}$ and $\mathrm{I}_{100}$ treatments, WP was 28 and 32.5\% higher than under low amount of N, for 2019 and 2020 growing seasons, respectively.

NUptake was significantly and positively affected by the increase in water and $\mathrm{N}$ supply and considerably higher in 2019 than in 2020. A significant interaction was also observed between WR and N levels in both growing seasons.

\subsection{Optimal Spectral Bands}

Table 3 shows the results of the principal components analysis carried out on $61(10 \mathrm{~nm})$ bands. The first two principal components (PCs) were associated with eigenvalues higher than one and explained 97.12 and $97.16 \%$ of the total variance in the 2019 and 2020 growing seasons, respectively. The first component was dominated by red-edge and green in 2019, and by red-edge and blue in 2020. The second component was dominated by NIR for both growing seasons.

\subsection{Optimal Vegetation Indices}

Correlations amongst variables were firstly checked using a Person correlation matrix (Figure 1). From this matrix, VIs were checked for correlation with yield, WP, NUptake, and physiological variables (A, gs, WUEi, Tr and LCC). For both growing seasons, the second principal component (F2, summarizing the contribution of NIR wavelengths) showed a strong positive relationship $(r>0.4)$ with all variables, except yield and WP in 2020. The first principal component (F1, summarizing the contribution of red-edge and green in 2019, and blue in 2020) showed a weak negative relationship with LCC in 2019 and a moderate negative relationship with WUEi in 2020.

The water indices (WBI, NWI1, NWI2, and WBI:NDVI) were strongly negatively correlated with NUptake and physiological variables for both growing seasons, except for NWI2 and WBI:NDVI, which were not correlated with LCC in 2020. In addition, in 2019, WBI, NWI1, and WBI:NDVI were strongly negatively correlated with yield and WP, while no significant correlations were observed in 2020.

The chlorophyll indices (Clgreen, Clred-edge, and Clred-edge710), DD, and DPI showed a strong positive relationship with yield, WP, NUptake, and physiological variables for both growing seasons except for: (i) Clgreen, which was not correlated with GY and WP in 2020; (ii) Clred-edge, which was not correlated with WUEi in 2020; and (iii) DPI, which was not correlated to either GY or WP in 2019, nor to GY, gs, Tr, or LCC in 2020.

For broad-band greenness indices (NDVI, RDVI, SAVI, OSAVI, GNDVI, and EVI) there were strong positive relationships with yield, WP, NUptake, and physiological variables for both growing seasons, except for GY and WP, which had no correlations in 2020, except for GNDVI. Also, EVI was not correlated with GY or WP in 2019, or with WUEi in 2020. 
Table 2. Effects of irrigation regime and nitrogen levels on fresh grain yield (GY), agronomic water productivity (WP), and nitrogen uptake (NUptake) of sweet maize plants grown in 2019 and 2020.

\begin{tabular}{|c|c|c|c|c|c|c|c|}
\hline \multirow{3}{*}{\multicolumn{2}{|c|}{ Treatment }} & \multirow{2}{*}{\multicolumn{2}{|c|}{$\frac{G Y}{\left(t^{h a^{-1}}\right)}$}} & \multirow{2}{*}{\multicolumn{2}{|c|}{$\frac{W P}{\left(\mathrm{~kg} \mathrm{~m}^{-3}\right)}$}} & \multirow{2}{*}{\multicolumn{2}{|c|}{$\begin{array}{l}\text { NUptake } \\
\left(\mathrm{kg} \mathrm{ha}^{-1}\right)\end{array}$}} \\
\hline & & & & & & & \\
\hline & & \multirow[t]{2}{*}{2019} & \multirow[t]{2}{*}{2020} & \multirow[t]{2}{*}{2019} & \multirow[t]{2}{*}{2020} & \multirow[t]{2}{*}{2019} & \multirow[t]{2}{*}{2020} \\
\hline Water Regime (WR) & Nitrogen(N) & & & & & & \\
\hline \multirow[t]{2}{*}{$\mathrm{I}_{0}$} & Low & - & - & - & - & $62.81 \pm 4.04 \mathrm{~d}$ & $39.57 \pm 2.81 \mathrm{~d}$ \\
\hline & High & - & - & - & - & $69.38 \pm 8.86 \mathrm{~d}$ & $52.67 \pm 6.4 \mathrm{~cd}$ \\
\hline & & - & - & - & - & $66.09 \pm 7.14 b$ & $46.12 \pm 8.43 b$ \\
\hline $\mathrm{I}_{50}$ & Low & $2.66 \pm 0.95$ & $7.56 \pm 0.51$ & $1.03 \pm 0.37 c$ & $3.74 \pm 0.25$ & $155.38 \pm 26.81 \mathrm{c}$ & $94.49 \pm 15.38 \mathrm{bc}$ \\
\hline Average & & $4.43 \pm 2.03 b$ & $8.65 \pm 1.61 b$ & $1.71 \pm 0.78 b$ & $4.28 \pm 0.80$ & $185.28 \pm 38.29 \mathrm{a}$ & $145.2 \pm 57.1$ a \\
\hline \multirow{2}{*}{$\mathrm{I}_{100}$} & Low & $15.88 \pm 0.28$ & $13.33 \pm 2.08$ & $3.97 \pm 0.07 \mathrm{a}$ & $3.84 \pm 0.60$ & $159.8 \pm 27.76 \mathrm{c}$ & $107.76 \pm 14.27 \mathrm{~b}$ \\
\hline & High & $16.02 \pm 1.81$ & $18.09 \pm 1.31$ & $4.00 \pm 0.45 \mathrm{a}$ & $5.21 \pm 0.38$ & $280.58 \pm 29.52 \mathrm{a}$ & $223.04 \pm 41.34 \mathrm{a}$ \\
\hline \multicolumn{8}{|l|}{ Significance } \\
\hline Water Regime (WR) & & $*$ & $* *$ & * & ns & $* *$ & $* *$ \\
\hline Nitrogen $(\mathrm{N})$ & & ns & * & * & $* *$ & $* * * *$ & $* * * *$ \\
\hline $\mathrm{WR} \times \mathrm{N}$ & & ns & ns & * & ns & $* * * *$ & $* *$ \\
\hline
\end{tabular}

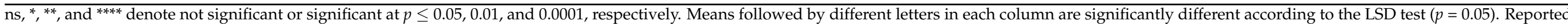

values are averages of three replicates. 
Table 3. Results of PCA carried out on the $61(10 \mathrm{~nm})$ bands. For mid-season phenological stage, the spectral bands with the largest loadings on the selected principal components (PCs) are reported.

\begin{tabular}{|c|c|c|c|c|c|c|c|c|c|c|c|c|}
\hline \multirow{2}{*}{ Growing Season } & \multicolumn{2}{|c|}{ Percentage of Variance Explained } & \multicolumn{10}{|c|}{ Bands Centers (nm) with Largest PC Loadings } \\
\hline & PC1 & PC2 & \multicolumn{5}{|c|}{ PC1 } & \multicolumn{5}{|c|}{ PC2 } \\
\hline 2019 & 71.49 & 25.63 & 530 & 540 & 550 & 720 & 730 & 780 & 790 & 800 & 860 & 870 \\
\hline 2020 & 78.63 & 18.53 & 420 & 430 & 440 & 720 & 730 & 760 & 770 & 780 & 790 & 800 \\
\hline
\end{tabular}
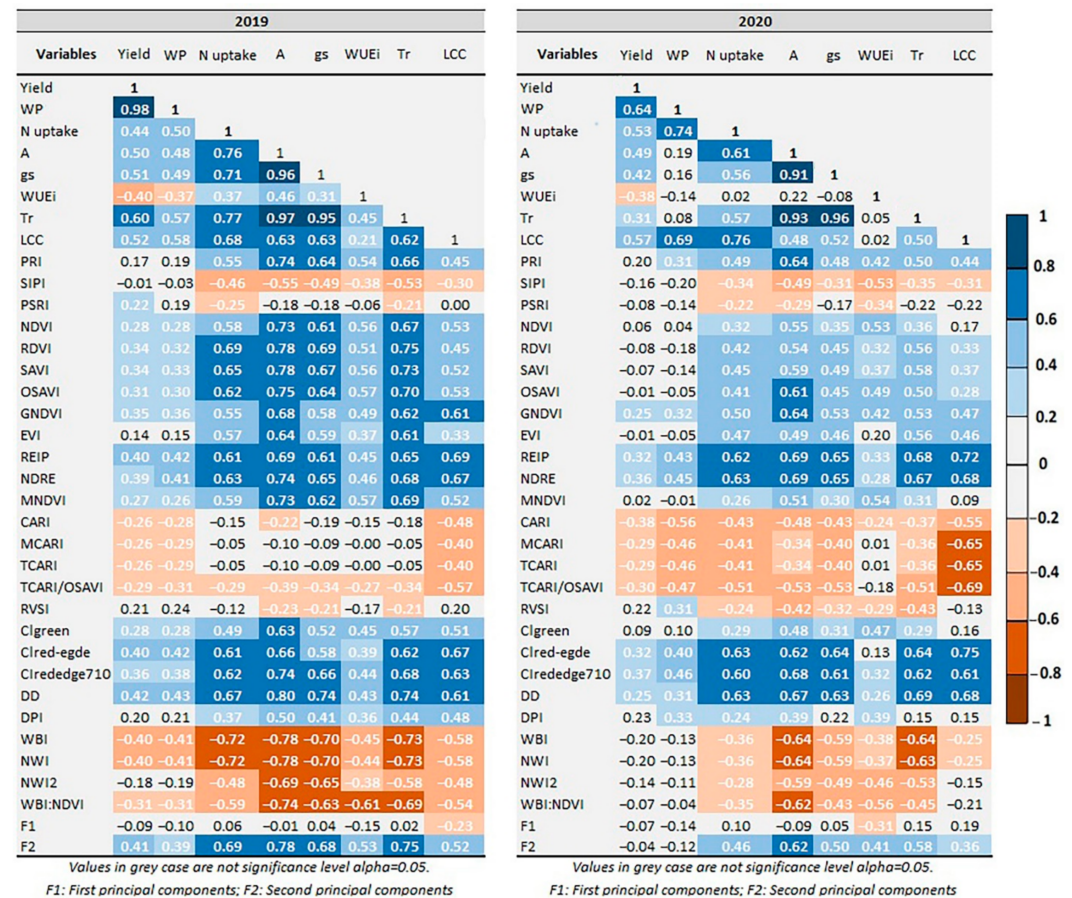

Figure 1. Correlations coefficients among fresh grain yield (GY), agronomic water productivity (WP), nitrogen uptake (NUptake), physiological variables, and vegetation indices for the 2019 and 2020 growing seasons.

The Chlorophyll Absorption Reflectance Index (CARI) and its derivatives (MCARI, TCARI, and TCARI/OSAVI) were negatively correlated with GY, WP, NUptake, and physiological variables in 2020, except for WUEi, which was negatively correlated only to CARI. In 2019, CARI and its derivatives were negatively correlated with GY, WP, and LCC. In addition, TCARI/OSAVI was moderately negatively correlated with all the investigated variables. Finally, A was weakly negatively correlated with CARI.

Table 4 shows stepwise regression models explaining GY, WP, NUptake, and physiological variables variation from VIs across different water supplies and nitrogen levels in 2019 and 2020 growing seasons.

The best VIs explanatory variables to predict GY were the DD and CARI indices in 2019 and 2020, respectively. However, the determination coefficients $\left(R^{2}\right)$ of the regression model was low, with values of 0.18 in 2019 and 0.14 in 2020. Similar results were obtained for WP; in addition, in 2020, PSRI was also selected, although it explained only a low portion of the total variance. In 2019,57\% of the NUptake was explained by the DD and water indices (WBI and NWI2), whereas in 2020,40\% of the NUptake was explained by the DD index alone. 
Table 4. Multivariate regression models explaining fresh grain yield (GY), agronomic water productivity (WP), nitrogen uptake (NUptake), and physiological variables from vegetation indices (VIs) across different water supplies and nitrogen treatment in the 2019 and 2020 growing seasons.

\begin{tabular}{|c|c|c|c|c|c|c|c|c|c|c|c|}
\hline $\begin{array}{l}\text { Year } \\
2019\end{array}$ & $\begin{array}{l}\text { Response } \\
\text { Variables }\end{array}$ & VIs & Coefficients & $p$-Value & $\begin{array}{c}\text { Portion of } \\
\text { Variation }\end{array}$ & $\begin{array}{l}\text { Year } \\
2020\end{array}$ & $\begin{array}{l}\text { Response } \\
\text { Variables }\end{array}$ & VIs & Coefficients & $p$-Value & $\begin{array}{c}\text { Portion of } \\
\text { Variation }\end{array}$ \\
\hline & \multirow{2}{*}{$\begin{array}{c}\mathrm{GY} \\
\left(\mathrm{R}^{2}=0.18\right. \\
\left.\mathrm{R}_{\mathrm{adj}}{ }^{2}=0.16\right)\end{array}$} & Intercept & -0.500 & 0.873 & & & \multirow{2}{*}{$\begin{array}{c}\mathrm{GY} \\
\left(\mathrm{R}^{2}=0.14\right. \\
\left.\mathrm{R}_{\mathrm{adj}}{ }^{2}=0.13\right)\end{array}$} & Intercept & 20.104 & 0.0001 & \\
\hline & & DD & 16.773 & 0.0008 & 1 & & & CARI & -94.762 & 0.0078 & 1 \\
\hline & \multirow{3}{*}{$\begin{array}{c}\text { WP } \\
\left(\mathrm{R}^{2}=0.18\right. \\
\left.\mathrm{R}_{\mathrm{adj}}{ }^{2}=0.17\right)\end{array}$} & Intercept & 0.559 & 0.396 & \multirow{3}{*}{1} & & \multirow{3}{*}{$\begin{array}{c}\text { WP } \\
\left(\mathrm{R}^{2}=0.38\right. \\
\left.\mathrm{R}_{\mathrm{adj}}{ }^{2}=0.35\right)\end{array}$} & Intercept & 6.849 & 0.0001 & \\
\hline & & \multirow[t]{2}{*}{ DD } & \multirow[t]{2}{*}{3.589} & \multirow[t]{2}{*}{0.0007} & & & & CARI & -28.119 & 0.0001 & 0.32 \\
\hline & & & & & & & & PSRI & -25.064 & 0.047 & 0.06 \\
\hline & \multirow{3}{*}{$\begin{array}{c}\text { NUptake } \\
\left(\mathrm{R}^{2}=0.57\right. \\
\left.\mathrm{R}_{\mathrm{adj}}{ }^{2}=0.56\right)\end{array}$} & Intercept & 2852.72 & 0.0001 & & & \multirow{3}{*}{$\begin{array}{c}\text { NUptake } \\
\left(\mathrm{R}^{2}=0.40\right. \\
\left.\mathrm{R}_{\mathrm{adj}}{ }^{2}=0.39\right)\end{array}$} & Intercept & 51.555 & 0.0001 & \\
\hline & & DD & 113,25 & 0.038 & 0.02 & & & $\mathrm{DD}$ & 638.45 & 0.0001 & 1 \\
\hline & & $\begin{array}{c}\text { WBI } \\
\text { NWI2 }\end{array}$ & $\begin{array}{c}-3266.25 \\
1456.42\end{array}$ & $\begin{array}{c}0.0001 \\
0.005\end{array}$ & $\begin{array}{l}0.52 \\
0.03\end{array}$ & & & & & & \\
\hline & \multirow{5}{*}{$\begin{array}{c}\mathrm{A} \\
\left(\mathrm{R}^{2}=0.77\right. \\
\left.\mathrm{R}_{\mathrm{adj}}{ }^{2}=0.76\right)\end{array}$} & Intercept & -148.048 & 0.0001 & & & \multirow{5}{*}{$\begin{array}{c}\mathrm{A} \\
\left(\mathrm{R}^{2}=0.54\right. \\
\left.\mathrm{R}_{\mathrm{adj}}^{2}=0.53\right)\end{array}$} & Intercept & -1493.387 & 0.0018 & \\
\hline & & PSRI & 217.972 & 0.0082 & 0.02 & & & REIP & 2.457 & 0.0001 & 0.48 \\
\hline & & OSAVI & -951.677 & 0.0001 & 0.04 & & & WBI & -251.036 & 0.003 & 0.06 \\
\hline & & RVSI & -132.312 & 0.0001 & 0.04 & & & & & & \\
\hline & & DD & 100.540 & 0.0001 & 0.64 & & & & & & \\
\hline & \multirow{4}{*}{$\begin{array}{c}\text { gs } \\
\left(\mathrm{R}^{2}=0.56\right. \\
\left.\mathrm{R}_{\mathrm{adj}}{ }^{2}=0.55\right)\end{array}$} & Intercept & -0.435 & 0.0196 & & & \multirow{4}{*}{$\begin{array}{c}\text { gs } \\
\left(\mathrm{R}^{2}=0.51\right. \\
\left.\mathrm{R}_{\mathrm{adj}}^{2}=0.49\right)\end{array}$} & Intercept & -12.726 & 0.0026 & \\
\hline & & DD & 0.353 & 0.0001 & 0.54 & & & REIP & 0.018 & 0.0027 & 0.42 \\
\hline & & NWI2 & -1.393 & 0.0496 & 0.02 & & & NWI1 & -15.460 & 0.0027 & 0.05 \\
\hline & & & & & & & & NWI2 & 8.018 & 0.0173 & 0.04 \\
\hline & \multirow{4}{*}{$\begin{array}{c}\text { WUEi } \\
\left(\mathrm{R}^{2}=0.40\right. \\
\left.\mathrm{R}_{\mathrm{adj}}^{2}=0.39\right)\end{array}$} & Intercept & 650.856 & 0.0001 & & & \multirow{4}{*}{$\begin{array}{c}\text { WUEi } \\
\left(\mathrm{R}^{2}=0.55\right. \\
\left.\mathrm{R}_{\text {adj }}^{2}=0.53\right)\end{array}$} & Intercept & -33427 & 0.0001 & \\
\hline & & WBI:NDVI & -393.984 & 0.0001 & 0.37 & & & REIP & 48.306 & 0.0001 & 0.12 \\
\hline & & $\begin{array}{c}\text { Clred- } \\
\text { edge710 }\end{array}$ & -63.419 & 0.0444 & 0.03 & & & NDRE & -2702.998 & 0.0001 & 0.08 \\
\hline & & & & & & & & WBI:NDVI & -338.300 & 0.0001 & 0.31 \\
\hline
\end{tabular}


Table 4. Cont.

\begin{tabular}{|c|c|c|c|c|c|c|c|c|c|c|c|}
\hline $\begin{array}{l}\text { Year } \\
2019\end{array}$ & $\begin{array}{l}\text { Response } \\
\text { Variables }\end{array}$ & VIs & Coefficients & $p$-Value & $\begin{array}{c}\text { Portion of } \\
\text { Variation }\end{array}$ & $\begin{array}{l}\text { Year } \\
2020\end{array}$ & $\begin{array}{l}\text { Response } \\
\text { Variables }\end{array}$ & VIs & Coefficients & $p$-Value & $\begin{array}{l}\text { Portion of } \\
\text { Variation }\end{array}$ \\
\hline & \multirow{3}{*}{$\begin{array}{c}\mathrm{Tr} \\
\left(\mathrm{R}^{2}=0.60\right. \\
\left.\mathrm{R}_{\mathrm{adj}}{ }^{2}=0.59\right)\end{array}$} & Intercept & -9.712 & 0.0001 & & & \multirow{3}{*}{$\begin{array}{c}\mathrm{Tr} \\
\left(\mathrm{R}^{2}=0.59\right. \\
\left.\mathrm{R}_{\mathrm{adj}}{ }^{2}=0.58\right)\end{array}$} & Intercept & 185.980 & 0.0002 & \\
\hline & & RDVI & 12.230 & 0.0001 & 0.56 & & & $\mathrm{DD}$ & 14.365 & 0.0004 & 0.48 \\
\hline & & NDRE & 12.219 & 0.0040 & 0.04 & & & $\begin{array}{l}\text { WBI } \\
\text { NWI2 }\end{array}$ & $\begin{array}{c}-186.011 \\
188.534\end{array}$ & $\begin{array}{l}0.0002 \\
0.0034\end{array}$ & $\begin{array}{l}0.06 \\
0.05\end{array}$ \\
\hline & \multirow{5}{*}{$\begin{array}{c}\text { LCC } \\
\left(\mathrm{R}^{2}=0.48\right. \\
\left.\mathrm{R}_{\mathrm{adj}}{ }^{2}=0.47\right)\end{array}$} & Intercept & -22399 & 0.0001 & & & \multirow{5}{*}{$\begin{array}{c}\text { LCC } \\
\left(\mathrm{R}^{2}=0.69\right. \\
\left.\mathrm{R}_{\mathrm{adj}}{ }^{2}=0.67\right)\end{array}$} & Intercept & -1297.836 & 0.1258 & \\
\hline & & REIP & 32.007 & 0.0001 & 1 & & & PRI & 4227.144 & 0.0005 & 0.03 \\
\hline & & & & & & & & GNDVI & -1423.275 & 0.0004 & 0.03 \\
\hline & & & & & & & & Clred-edge & 2020.674 & 0.0001 & 0.56 \\
\hline & & & & & & & & WBI & 2036.023 & 0.0118 & 0.05 \\
\hline
\end{tabular}


Among five vegetation indices (DD, PSRI, OSAVI, MNDVI, and RVSI) selected to predict photosynthesis assimilation (A) in 2019, DD provided the most accurate estimation $\left(R^{2}=0.64\right)$. In $2020,54 \%$ of A was explained by the REIP and WBI indices. In particular, REIP outperformed the WBI index in providing an accurate estimation of $A\left(R^{2}=0.48\right)$.

In 2019, the DD index provided a greater ability to explain conductance (gs) as compared to NWI2, while in 2020, REIP provided more accurate estimation of gs than NWI1 and NWI2 $\left(\mathrm{R}^{2}=0.42\right)$.

The best model, with two (Clred-edge710 and WBI: NDVI) and three (REIP, NDRE, and WBI:NDVI) indices, was selected to predict WUEi in the 2019 and 2020 growing seasons, respectively. The WBI:NDVI ratio provided the most accurate estimation of WUEi, with a $\mathrm{R}^{2}$ of 0.37 and 0.31 in 2019 and 2020 , respectively.

In 2019,60\% of Tr was explained by the RDVI and NDRE indices, with the RDVI index providing the most accurate estimation of $\operatorname{Tr}\left(\mathrm{R}^{2}=0.56\right)$. On the other hand, DD, WBI, and NWI2 were selected to predict Tr in 2020, with the DD index explaining $48 \%$ of the data variation of Tr.

In 2020,69\% of the total variation in LCC under different N supply and water regimes was explained by the PRI, GNDVI, Clred-edge, and WBI indices, with the chlorophyll index (Clred-edge) providing the most accurate estimation of the response variable $\left(R^{2}=0.56\right)$. In $2019,48 \%$ of the LCC was explained by the REIP index alone.

From the results of the stepwise regression analysis, the linear regressions showing the highest ability to explain some physiological variables (net assimilation, stomatal conductance, and leaf chlorophyll content), with the VIs, are presented in Figure 2. 

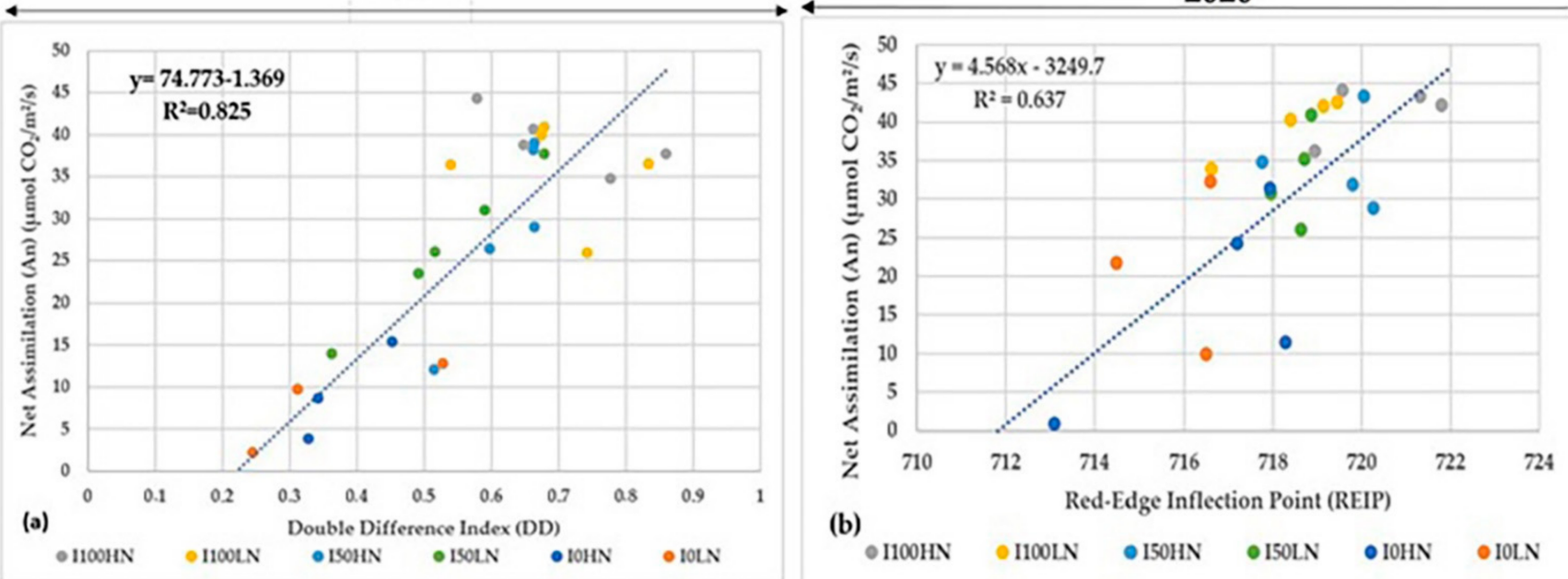

(b)

- $1100 \mathrm{HN} \bullet \mathrm{I100LN} \bullet \mathrm{ISOHN} \bullet \mathrm{ISOLN} \bullet \mathrm{HOHN} \bullet \mathrm{HOLN}$

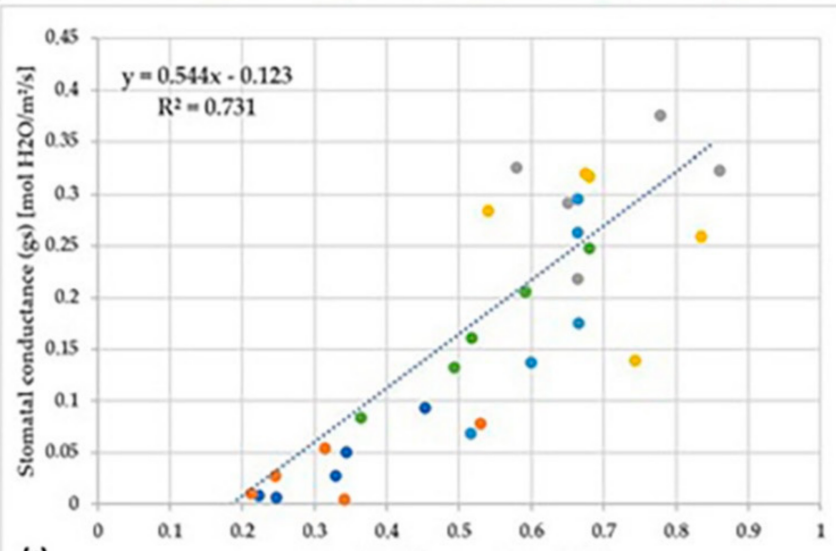

(c) Double Difference Index (DD)

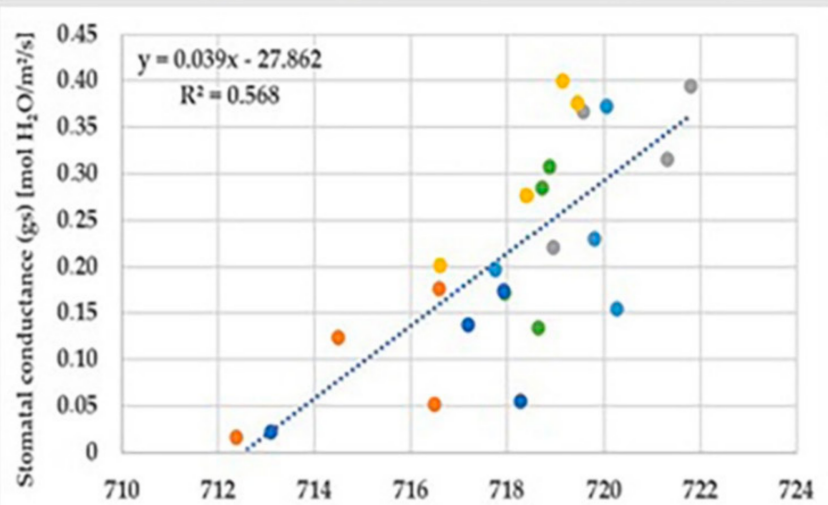

(d)

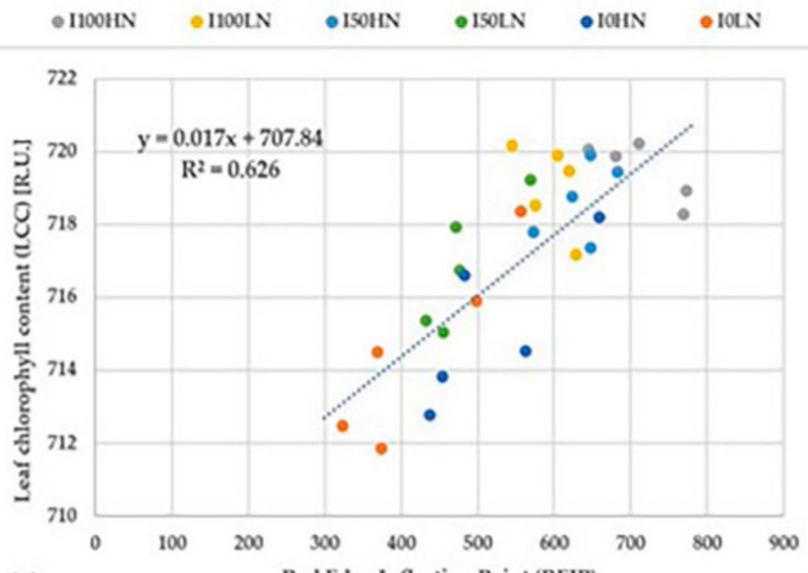

(e) Red Edge Inflection Point (REIP)

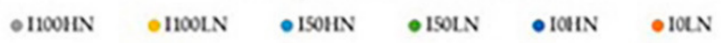

$\bullet \mathrm{I} 100 \mathrm{HN} \bullet \mathrm{I} 100 \mathrm{LN} \bullet \mathrm{I} 50 \mathrm{HN} \bullet 150 \mathrm{LN} \bullet \mathrm{I0HN} \bullet \mathrm{I0LN}$

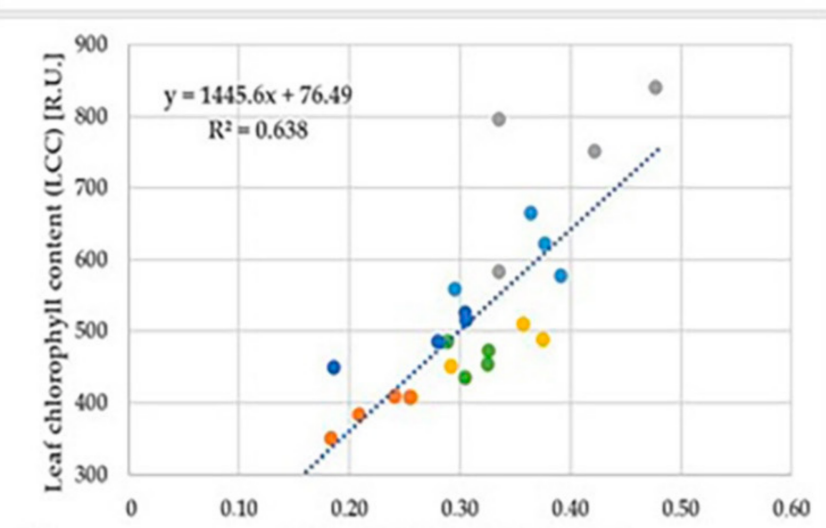

(f)

-I100HN

Figure 2. Linear regression parameters between net assimilation $(\mathbf{a}, \mathbf{b})$, stomatal conductance (c,d), and Double Difference Index (DD) and Red-edge Inflection Point (REIP), respectively. Linear regression parameters between leaf chlorophyll content $(\mathbf{e}, \mathbf{f})$ and Red-edge Inflection Point (REIP) and Chlorophyll Index (Clred-edge), respectively. Each value is the mean of three replicates.

\section{Discussion}

\subsection{Fresh Grain Yield, Agronomic Water Productivity and Nitrogen Uptake}

Water and nitrogen $(\mathrm{N})$ have been recognized as two primary limiting resources for maize production $[82,83]$. The maximum fresh grain yield values for well-irrigated and fertilized treatments were 16.0 and $18.1 \mathrm{t} \mathrm{ha}^{-1}$ in the 2019 and 2020 growing seasons, 
respectively. As a consequence of severe drought experienced by the crop in both years (seasonal precipitation was 119 and $56 \mathrm{~mm}$ in 2019 and 2020, respectively), the rainfed treatment did not reach the reproductive stage, because of either abortion of the floral ovary at the time of pollination, or, even worse, the failure of many silks to emerge from the husks, preventing fertilization. Several other studies (e.g., [84-86]) reported that intense and prolonged water shortage in maize seriously compromises yield due to the lack of pollination.

As an average of the two years, WP ranged from $3.0 \mathrm{~kg} \mathrm{~m}^{-3}$ in $\mathrm{I}_{50}$ to $4.26 \mathrm{~kg} \mathrm{~m}^{-3}$ in $\mathrm{I}_{100}$, which means that, under deficit irrigation conditions, less grain was produced per volume of water, compared with well irrigated conditions. The WP values found in our study are similar to those reported by Kresovic et al. [87] for maize cultivated in Serbia under different irrigation regimes. Similar to our findings, Farré and Faci [88] reported that the WP of maize decreases with decreasing irrigation volumes in a Mediterranean area.

The highest values of NUptake were obtained in fully irrigated and fertilized regimes, with values of $280.6 \mathrm{~kg} \mathrm{ha}^{-1}$ and $223.4 \mathrm{~kg} \mathrm{ha}^{-1}$ in 2019 and 2020, respectively. NUptake in fully irrigated and low fertilized treatment decreased by $43 \%$ in 2019 and $51 \%$ in 2020 . However, values in the $\mathrm{I}_{50} \mathrm{HN}$ treatment averaged $215.2 \mathrm{~kg} \mathrm{ha}^{-1}$ in 2019 and $195.9 \mathrm{~kg} \mathrm{ha}^{-1}$ in 2020, reduced by $28 \%$ and $52 \%$ in the $\mathrm{I}_{50} \mathrm{LN}$ treatment, respectively. Hence, our results highlight the importance of $\mathrm{N}$ fertilization and optimum water supply, which can facilitate crop $\mathrm{N}$ uptake, as irrigation increased $\mathrm{N}$ uptake and the ability of maize to efficiently use $\mathrm{N}$ from the soil. The results of our study confirm previously reported findings by several authors $[89,90]$. Plant $\mathrm{N}$ uptake is facilitated through optimum irrigation; thus, both nitrogen and water use efficiencies may be simultaneously improved.

\subsection{Spectral Reflectance}

The principal component analysis (PCA) was conducted to identify optimal spectral bands for separating different combinations of water and $\mathrm{N}$ availability at the mid-season stage of both growing seasons. Reflectance in the green region is controlled by leaf color, whereas the wavebands in coastal blue are related to chlorophyll absorption, which peaks at 430-450 [59]. Wavebands from the red-edge region are the most sensitive to stress-induced changes. The shape of the red-edge region has been shown to be strongly influenced by chlorophyll content, such that an increase in leaf chlorophyll content causes a shift in the red-edge position towards longer wavelengths [91]. The red-edge wavelength ranges between 690 and $750 \mathrm{~nm}$; the occurrence of a sharp change in reflectance indicates a transition from chlorophyll absorption to leaf scattering [92]. Moreover, the differences in red edge position (up to $10 \mathrm{~nm}$ ) in many studies were explained as the result of various factors, such as water stress [2,93], nutrient deficiency [94], plant disease [95], etc. On the other hand, internal leaf structure controls the NIR. The separation between coastal blue or green and red-edge, on one side, and NIR on the other side, were reported by several authors in many species $[23,96,97]$. The difference in spectral behavior in the visible region could be due to differences in the concentrations of biochemical substances, such as chlorophyll, carotenoid, nitrogen, and water, in the intra- and extracellular leaf structure. Therefore, healthy vegetation can be identified by high NIR reflectance and low visible reflectance, and even more precisely by analyzing reflectance in narrow bands. The selection of optimal wavelengths through principal component analysis in our study underlined the separation between visible and NIR reflectance, and the role of red-edge region wavelengths in characterizing the sweet maize response to water and nitrogen stress in both growing seasons.

\subsection{Spectral Indices}

Multiple linear regression, with a stepwise algorithm, was used to select the VIs most able to estimate fresh grain yield, physiological variables, water productivity, and $\mathrm{N}$ uptake. The poor performance of the stepwise algorithm in selecting VIs for some response variables (GY and WP), also confirmed by the low $R^{2}$ and $R_{a d j}{ }^{2}$ values, might be attributed to the 
high influence of collinearity of the predictors [98]. As Strachan et al. [99] reported, several VIs are needed to detect the stress status and health of maize. Many studies found that rededge derived indices outperformed broadband indices [100-102]. However, in our study, broadband indices (NDVI, RDVI, SAVI, OSAVI, GNDVI, and EVI) show strong positive correlations with all investigated variables. This finding is in agreement with previous studies [103-106]. In the multivariate regression results, the red-edge group indices, such as CARI, DD, REIP, and the Clred-edge chlorophyll index, were observed to be better predictors, particularly of yield and physiological parameters (A, gs, and LCC) at the midseason stage, when differences among water supplies and nitrogen treatment are mainly related to chlorophyll content. This result confirms the role of the red-edge spectral region that emerged from the principal component analysis. The DD, REIP, and Clred-edge VIs can be used to discriminate temporary stress at the mid-season stage, or separate levels of water and $\mathrm{N}$ stress. Generally, these indices are sensitive to small variations of chlorophyll content and are reliable for most species, due to the presence of the red-edge region [107-109]. As previously reported, the high sensitivity to chlorophyll content highlights the importance of using red-edge-based VIs to characterize plant $\mathrm{N}$ deficiency and $\mathrm{N}$ requirement in the mid-season stage of sweet maize. According to Vogelmann et al. [77], the red-edge position is related to environmental, developmental, and genetic factors that result in altered chlorophyll levels, and the red-edge position does not necessarily diagnose one particular type of stress. Here, the shift in red-edge position may be related to changes in the width of the maximum chlorophyll absorption in the red spectral region [110], caused by the reduced activity of chlorophyll, and lower photosynthetic capacity as a consequence of low nitrogen supply. In addition, Ramachandiran and Pazhanivelan [111] reported similar results. A relatively strong negative correlation was found between CARI index and its derivatives (MCARI, TCARI and TCARI/OSAVI) and both yield and physiological parameters (A, gs, and LCC), especially in the 2020 growing season. Zhang et al. [2] showed a similar negative correlation between the MCARI index and leaf chlorophyll content. In addition, at later development stages close to harvest, when structural indices are not responsive to yield variability, the hyperspectral indices related to chlorophyll status (CARI and its derivatives) better reflect within-field yield variability [112]. Besides that, our results demonstrated a strong positive correlation between chlorophyll indices (Clgreen, Clred-edge and Clred-edge710), DD and DPI, and physiological parameters, in agreement with some previous studies [113-115]. This result confirms the critical role and sensitivity of the red-edge region $(680-780 \mathrm{~nm})$ to chlorophyll and nitrogen $[43,116,117]$.

A negative correlation was found between canopy water VIs and both NUptake and physiological parameters (Figure 1). Water VIs are described in the literature as effective indicators of water stress and show a strong correlation with physiological variables [118,119], as was observed in our study. Under short-time water stress, crops adopt photo-protection strategies to prevent damages; however, under prolonged water stress, chlorophyll pigments are affected and changes in leaf optical properties occur [2]. Generally, wavelengths between 900 and $1300 \mathrm{~nm}$ have strong correlations with leaf water content [120] and are effective predictors, as they can penetrate into canopies better than the rapidly-absorbed higher wavelengths [121].

The canopy water content vegetation indices (WBI and WBI:NDVI) use the reflectance at $970 \mathrm{~nm}$ to indicate water absorption, and a reference wavelength reflectance at $900 \mathrm{~nm}$. This wavelength is used because there is no absorption by water at $900 \mathrm{~nm}$, but it is subjected to the same changes in sample structure as the reading at $970 \mathrm{~nm}$ [122]. Several authors show [123-125] that the WBI is higher in the initial or later stages of a nitrogenstressed crop. According to Ramachandiran and Pazhanivelan [107], the plants with high nitrogen status have lower values of WBI, and vice versa.

A decrease in NIR reflectance for stressed plants is mainly due to a decrease in LAI and green biomass [125], and reduced turgidity of the spongy-mesophyll layer in rainfed crops, compared to the turgidity levels of fully irrigated crops [111]. However, as the degree of absorption at $970 \mathrm{~nm}$ rises compared to $900 \mathrm{~nm}$, the water content of plant canopies 
increases [76]. On the contrary, under water-stress conditions, the $970 \mathrm{~nm}$ trough of the reflectance spectrum tends to shift towards lower wavelengths.

\section{Conclusions}

The results of this study demonstrated that hyperspectral reflectance can be used as a tool to detect the water and nitrogen status of sweet maize, even if no single index can describe the complexity of the eco-physiological behavior of vegetation. The most effective indices to assess the combined effect of nitrogen and water stress in maize were red-edge based VIs, such as CARI, DD, REIP, and Clred-edge chlorophyll indices. Therefore, the use of spectral data at mid-season stage could enhance precision agriculture by identifying stress patterns, and aid growers in making good decisions; for instance, allowing supplemental water and nutrient application to mitigate adverse stress effects.

The relationship between the spectral signature and the target variable might be affected by structural properties of the canopy (i.e., plant size, age, and leaf angle) and physiological status, in response to biotic and abiotic stressors. Thus, in future perspectives, the integrated use of information derived by different sensors could help in discriminating the effects of multiple stresses on crop response.

Author Contributions: Conceptualization, M.H.S., R.A. and A.M.S.; methodology, M.H.S., M.Č., R.A. and A.M.S.; formal analysis and data curation, M.H.S., R.A. and A.M.S.; investigation, M.Č., M.H., V.C. and L.P.; writing—original draft preparation, M.H.S., R.A., M.Č. and A.M.S.; writing—review and editing, M.H.S., R.A., M.Č., V.C., M.T. and A.M.S.; funding acquisition, M.T. All authors have read and agreed to the published version of the manuscript.

Funding: The research was supported by the Master of Science Program in Water and Land Resources Management of CIHEAM Bari (Italy).

Institutional Review Board Statement: Not applicable.

Informed Consent Statement: Not applicable.

Data Availability Statement: Not applicable.

Acknowledgments: The authors thank Carlo Ranieri (CIHEAM Bari) for technical support during the acquisition of data and Mimmo Tribuzio (CIHEAM Bari) for agronomic assistance in the field.

Conflicts of Interest: The authors declare no conflict of interest.

\section{References}

1. Li, L.; Lin, D.; Wang, J.; Yang, L.; Wang, Y. Multivariate Analysis Models Based on Full Spectra Range and Effective Wavelengths Using Different Transformation Techniques for Rapid Estimation of Leaf Nitrogen Concentration in Winter Wheat. Front. Plant Sci. 2020, 11, 755. [CrossRef] [PubMed]

2. Zhang, F.; Zhou, G. Estimation of vegetation water content using hyperspectral vegetation indices: A comparison of crop water indicators in response to water stress treatments for summer maize. BMC Ecol. 2019, 19, 18. [CrossRef] [PubMed]

3. Shin, S.; Kim, S.G.; Lee, J.S.; Go, T.-H.; Shon, J.; Kang, S.; Lee, J.-S.; Bae, H.H.; Son, B.-Y.; Shim, K.-B.; et al. Impact of the consecutive days of visible wilting on growth and yield during tassel initiation in maize (Zea Mays L.). J. Crop Sci. Biotechnol. 2015, 18, 219-229. [CrossRef]

4. Massignam, A.M.; Chapman, S.C.; Hammer, G.L.; Fukai, S. Physiological determinants of maize and sunflower grain yield as affected by nitrogen supply. Field Crops Res. 2009, 113, 256-267. [CrossRef]

5. Leghari, S.J.; Wahocho, N.A.; Laghari, G.M.; HafeezLaghari, A.; MustafaBhabhan, G.; HussainTalpur, K.; Lashari, A.A. Role of nitrogen for plant growth and development: A review. Adv. Environ. Biol. 2016, 10, 209-219.

6. Maheswari, M.; Murthy, A.N.G.; Shanker, A.K. Nitrogen Nutrition in Crops and Its Importance in Crop Quality. In The Indian Nitrogen Assessment; Abrol, Y.P., Adhya, T.K., Aneja, V.P., Raghuram, N., Pathak, H., Kulshrestha, U., Eds.; Elsevier: Amsterdam, The Netherlands, 2017; pp. 175-186. [CrossRef]

7. Tilling, A.K.; O’Leary, G.J.; Ferwerda, J.G.; Jones, S.D.; Fitzgerald, G.J.; Rodriguez, D.; Belford, R. Remote sensing of nitrogen and water stress in wheat. Field Crops Res. 2007, 104, 77-85. [CrossRef]

8. $\quad$ Pinter, P.J., Jr.; Hatfield, J.L.; Schepers, J.S.; Barnes, E.M.; Moran, M.S.; Daughtry, C.S.; Upchurch, D.R. Remote sensing for crop management. Photogramm. Eng. Remote Sens. 2003, 69, 647-664.

9. Solari, F.; Shanahan, J.; Ferguson, R.; Schepers, J.; Gitelson, A. Active Sensor Reflectance Measurements of Corn Nitrogen Status and Yield Potential. J. Agron. 2008, 100, 571. [CrossRef] 
10. Walsh, O.S.; Klatt, A.R.; Solie, J.B.; Godsey, C.B.; Raun, W.R. Use of soil moisture data for refined GreenSeeker sensor based nitrogen recommendations in winter wheat (Triticum aestivum L.). Precis. Agric. 2013, 14, 343-356. [CrossRef]

11. Taghvaeian, S.; Chávez, J.L.; Hansen, N.C. Ground-based remote sensing of corn evapotranspiration under limited irrigation practices. In Proceedings of the 32nd Annual American Geophysical Union Hydrology Days, Fort Collins, CO, USA, 21-23 March 2012; pp. 119-131.

12. Genc, L.; Inalpulat, M.; Kizil, U.; Mirik, M.; Smith, S.E.; Mendes, M. Paprastojo kukuruzo (Zea mays L.) dregmes streso nustatymas, taikant spektrini atspindi ir klasifikavimo medžio metoda. Zemdirbyste 2013, 100, 81-90. [CrossRef]

13. DeJonge, K.C.; Mefford, B.S.; Chávez, J.L. Assessing corn water stress using spectral reflectance. Int. J. Remote Sens. 2016, 37, 2294-2312. [CrossRef]

14. Zhao, G.; Miao, Y.; Wang, H.; Su, M.; Fan, M.; Zhang, F.; Jiang, R.; Zhang, Z.; Liu, C.; Liu, P.; et al. A preliminary precision rice management system for increasing both grain yield and nitrogen use efficiency. Field Crop Res. 2013, 154, 23-30. [CrossRef]

15. Din, M.; Zheng, W.; Rashid, M.; Wang, S.; Shi, Z. Evaluating Hyperspectral Vegetation Indices for Leaf Area Index Estimation of Oryza sativa L. at Diverse Phenological Stages. Front. Plant Sci. 2017, 8, 820. [CrossRef] [PubMed]

16. Jones, H.G.; Vaughan, R.A. Remote Sensing of Vegetation: Principles, Techniques, and Applications; Jones, H.G., Vaughan, R.A., Eds.; Oxford University Press: Oxford, UK, 2010; p. 384. ISBN 978-0-19-920779-4.

17. Jain, N.; Ray, S.S.; Singh, J.P.; Panigrahy, S. Use of hyperspectral data to assess the effects of different nitrogen applications on a potato crop. Precis. Agric. 2007, 8, 225-239. [CrossRef]

18. Carter, G.A.; Knapp, A.K. Leaf optical properties in higher plants: Linking spectral characteristics to stress and chlorophyll concentration. Am. J. Bot. 2001, 88, 677-684. [CrossRef] [PubMed]

19. Mahajan, G.R.; Sahoo, R.N.; Pandey, R.N.; Gupta, V.K.; Kumar, D. Using hyperspectral remote sensing techniques to monitor nitrogen, phosphorus, sulphur and potassium in wheat (Triticum aestivum L.). Precis. Agric. 2014, 15, 499-522. [CrossRef]

20. Carter, G.A.; Estep, L. General Spectral Characteristics of Leaf Reflectance Responses to Plant Stress and Their Manifestation at the Landscape Scale. In From Laboratory Spectroscopy to Remotely Sensed Spectra of Terrestrial Ecosystems; Muttiah, R.S., Ed.; Springer: Dordrecht, The Netherlands, 2002; pp. 271-293. [CrossRef]

21. Feng, W.; Guo, B.-B.; Zhang, H.-Y.; He, L.; Zhang, Y.-S.; Wang, Y.-H.; Zhu, Y.-J.; Guo, T.-C. Remote estimation of above ground nitrogen uptake during vegetative growth in winter wheat using hyperspectral red-edge ratio data. Field Crops Res. 2015, 180, 197-206. [CrossRef]

22. Gómez-Casero, M.T.; Castillejo-González, I.L.; García-Ferrer, A.; Peña-Barragán, J.M.; Jurado-Expósito, M.; García-Torres, L.; López-Granados, F. Spectral discrimination of wild oat and canary grass in wheat fields for less herbicide application. Agron. Sustain. Dev. 2010, 30, 689-699. [CrossRef]

23. Stellacci, A.M.; Castrignanò, A.; Troccoli, A.; Basso, B.; Buttafuoco, G. Selecting optimal hyperspectral bands to discriminate nitrogen status in durum wheat: A comparison of statistical approaches. Environ. Monit. Assess. 2016, 188, 1-15. [CrossRef]

24. Ye, X.; Sakai, K.; Sasao, A.; Asada, S. Potential of airborne hyperspectral imagery to estimate fruit yield in citrus. Chemom. Intell. Lab. Syst. 2008, 90, 132-144. [CrossRef]

25. Kale, K.V.; Solankar, M.M.; Nalawade, D.B.; Dhumal, R.K.; Gite, H.R. A Research Review on Hyperspectral Data Processing and Analysis Algorithms. Proc. Natl. Acad. Sci. India Sect. A Phys. Sci. 2017, 87, 541-555. [CrossRef]

26. Thenkabail, P.S.; Enclona, E.A.; Ashton, M.S.; Van Der Meer, B. Accuracy assessments of hyperspectral waveband performance for vegetation analysis applications. Remote Sens. Environ. 2004, 91, 354-376. [CrossRef]

27. Choi, Y.H.; Kim, H.K.; Hazekamp, A.; Erkelens, C.; Lefeber, A.W.M.; Verpoorte, R. Metabolomic Differentiation ofCannabissativaCultivars Using1H NMR Spectroscopy and Principal Component Analysis. J. Nat. Prod. 2004, 67, 953-957. [CrossRef] [PubMed]

28. Stellacci, A.M.; Castrignanò, A.; Diacono, M.; Troccoli, A.; Ciccarese, A.; Armenise, E.; Gallo, A.; De Vita, P.; Lonigro, A.; Mastro, M.A.; et al. Combined approach based on principal component analysis and canonical discriminant analysis for investigating hyperspectral plant response. Ital. J. Agron. 2012, 7, 247-253. [CrossRef]

29. Ray, S.S.; Singh, J.P.; Panigraphy, S. Use of hyperspectral remote sensing data for crop stress detection: Ground-based studies. ISPRS Arch. 2010, 38, 562-570.

30. Krezhova, D.; Velichkova, K.; Petrov, N.; Maneva, S. The effect of plant diseases on hyperspectral leaf reflectance and biophysical parameters. In Proceedings of the 5th International Conference on Radiation and Application in Various Fields of Research (RAD-2017), Budva, Montenegro, 12-16 June 2017; pp. 11-16.

31. Morcillo-Pallarés, P.; Rivera-Caicedo, J.P.; Belda, S.; De Grave, C.; Burriel, H.; Moreno, J.; Verrelst, J. Quantifying the Robustness of Vegetation Indices through Global Sensitivity Analysis of Homogeneous and Forest Leaf-Canopy Radiative Transfer Models. Remote Sens. 2019, 11, 2418. [CrossRef]

32. Carlson, T.N.; Ripley, D.A. On the relation between NDVI, fractional vegetation cover, and leaf area index. Remote Sens. Environ. 1997, 62, 241-252. [CrossRef]

33. Huete, A. A soil-adjusted vegetation index (SAVI). Remote Sens. Environ. 1988, 25, 295-309. [CrossRef]

34. Rondeaux, G.; Steven, M.; Baret, F. Optimization of soil-adjusted vegetation indices. Remote Sens. Environ. 1996, 55, 95-107. [CrossRef]

35. Huete, A.; Didan, K.; Miura, T.; Rodriguez, E.; Gao, X.; Ferreira, L. Overview of the radiometric and biophysical performance of the MODIS vegetation indices. Remote Sens. Environ. 2002, 83, 195-213. [CrossRef] 
36. Gitelson, A.A.; Merzlyak, M.N. Remote sensing of chlorophyll concentration in higher plant leaves. Adv. Space Res. 1998, 22, 689-692. [CrossRef]

37. Cristiano, P.M.; Posse, G.; Di Bella, C.M.; Jaimes, F.R. Uncertainties in fPAR estimation of grass canopies under different stress situations and differences in architecture. Int. J. Remote Sens. 2010, 31, 4095-4109. [CrossRef]

38. Hansen, P.M.; Schjoerring, J.K. Reflectance measurement of canopy biomass and nitrogen status in wheat crops using normalized difference vegetation indices and partial least squares regression. Remote Sens. Environ. 2003, 86, 542-553. [CrossRef]

39. Glenn, E.; Huete, A.; Nagler, P.; Nelson, S. Relationship Between Remotely-sensed Vegetation Indices, Canopy Attributes and Plant Physiological Processes: What Vegetation Indices Can and Cannot Tell Us About the Landscape. Sensors 2008, 8, $2136-2160$. [CrossRef]

40. Haboudane, D. Hyperspectral vegetation indices and novel algorithms for predicting green LAI of crop canopies: Modeling and validation in the context of precision agriculture. Remote Sens. Environ. 2004, 90, 337-352. [CrossRef]

41. Gitelson, A.A.; Gritz, Y.; Merzlyak, M.N. Relationships between leaf chlorophyll content and spectral reflectance and algorithms for non-destructive chlorophyll assessment in higher plant leaves. J. Plant Physiol. 2003, 160, 271-282. [CrossRef]

42. Gitelson, A.A.; Keydan, G.P.; Merzlyak, M.N. Three-band model for noninvasive estimation of chlorophyll, carotenoids, and anthocyanin contents in higher plant leaves. Geophys. Res. Lett. 2006, 33. [CrossRef]

43. Wu, C.; Niu, Z.; Tang, Q.; Huang, W. Estimating chlorophyll content from hyperspectral vegetation indices: Modeling and validation. Agric. For. Meteorol. 2008, 148, 1230-1241. [CrossRef]

44. Main, R.; Cho, M.A.; Mathieu, R.; O'Kennedy, M.M.; Ramoelo, A.; Koch, S. An investigation into robust spectral indices for leaf chlorophyll estimation. ISPRS J. Photogramm. Remote Sens. 2011, 66, 751-761. [CrossRef]

45. Horler, D.N.H.; Dockray, M.; Barber, J. The red edge of plant leaf reflectance. Int. J. Remote Sens. 1983, 4, 273-288. [CrossRef]

46. Prasad, B.; Carver, B.F.; Stone, M.L.; Babar, M.A.; Raun, W.R.; Klatt, A.R. Genetic Analysis of Indirect Selection for Winter Wheat Grain Yield Using Spectral Reflectance Indices. Crop Sci. 2007, 47, 1416. [CrossRef]

47. Peñuelas, J.; Pinol, J.; Ogaya, R.; Filella, I. Estimation of plant water concentration by the reflectance Water Index WI (R900/R970) Int. J. Remote Sens. 1997, 18, 2869-2875. [CrossRef]

48. Hayes, A. Multiple Linear Regression (MLR). 2021. Available online: https://www.investopedia.com/terms $/ \mathrm{m} / \mathrm{mlr}$.asp (accessed on 30 March 2021).

49. Huang, Z.; Turner, B.J.; Dury, S.J.; Wallis, I.R.; Foley, W.J. Estimating foliage nitrogen concentration from HYMAP data using continuum removal analysis. Remote Sens. Environ. 2004, 93, 18-29. [CrossRef]

50. Wang, F.; Huang, J.; Lou, Z. A comparison of three methods for estimating leaf area index of paddy rice from optimal hyperspectral bands. Precis. Agric. 2010, 12, 439-447. [CrossRef]

51. Romero, A.P.; Alarcón, A.; Valbuena, R.I.; Galeano, C.H. Physiological Assessment of Water Stress in Potato Using Spectral Information. Front. Plant Sci. 2017, 8. [CrossRef] [PubMed]

52. Kefauver, S.C.; Vicente, R.; Vergara-Díaz, O.; Fernandez-Gallego, J.A.; Kerfal, S.; Lopez, A.; Melichar, J.P.E.; Serret Molins, M.D.; Araus, J.L. Comparative UAV and Field Phenotyping to Assess Yield and Nitrogen Use Efficiency in Hybrid and Conventional Barley. Front. Plant Sci. 2017, 8. [CrossRef] [PubMed]

53. Gracia-Romero, A.; Kefauver, S.C.; Vergara-Díaz, O.; Zaman-Allah, M.A.; Prasanna, B.M.; Cairns, J.E.; Araus, J.L. Comparative Performance of Ground vs. Aerially Assessed RGB and Multispectral Indices for Early-Growth Evaluation of Maize Performance under Phosphorus Fertilization. Front. Plant Sci. 2017, 8, 4. [CrossRef] [PubMed]

54. Soil Survey Staff. In Keys to Soil Taxonomy, 12th ed.; USDA-Natural Resources Conservation Service: Washington, DC, USA, 2014 Available online: http:/ / www.nrcs.usda.gov/Internet/FSE_DOCUMENTS/nrcs142p2_051546.pdf (accessed on 30 March 2021).

55. Todorovic, M. An Excel-based tool for real time irrigation management at field scale. In Proceedings of the International Symposium on "Water and Land Management for Sustainable Irrigated Agriculture", Adana, Turkey, 4-8 April 2006; pp. 4-8.

56. Allen, R.G.; Pereira, L.S.; Raes, D.; Smith, M. Crop Evapotranspiration. In Guidelines for Computing Crop Water Requirements; Irrigation and Drainage Paper 56; Food and Agriculture Organization: Rome, Italy, 1998.

57. Piscitelli, L.; Colovic, M.; Aly, A.; Hamze, M.; Todorovic, M.; Cantore, V.; Albrizio, R. Adaptive Agricultural Strategies for Facing Water Deficit in Sweet Maize Production: A Case Study of a Semi-Arid Mediterranean Region. Water 2021, 13, 3285. [CrossRef]

58. Von Caemmerer, S.; Farquhar, G.D. Some relationships between the biochemistry of photosynthesis and the gas exchange of leaves. Planta 1981, 153, 376-387. [CrossRef]

59. Min, M.; Lee, W.S. Determination of Significant Wavelengths and Prediction of Nitrogen Content for Citrus. Trans. ASAE 2005, 48, 455-461. [CrossRef]

60. De Mendiburu, F. Una Herramienta de Analisis Estadistico Para la Investigacion Agricola. Ph.D. Thesis, Universidad Nacional de Ingenieria (UNI-PERU), Rímac, Peru, 2009.

61. Wobbrock, J.O.; Findlater, L.; Gergle, D.; Higgins, J.J. The aligned rank transform for nonparametric factorial analyses using only anova procedures. In Proceedings of the 2011 Annual Conference on Human Factors in Computing Systems-CHI '11, British Columbia, BC, Canada, 7-12 May 2022; ACM Press: New York, USA, 2011; pp. 143-146. [CrossRef]

62. R Core Team. R: A Language and Environment for Statistical Computing; R Foundation for Statistical Computing: Vienna, Austria, 2013. Available online: https://www.scirp.org/(S(vtj3fa45qm1ean45vvffcz55))/reference/ReferencesPapers.aspx?ReferenceID= 1742158 (accessed on 1 March 2021). 
63. Addinsoft. XLSTAT Statistical and Data Analysis Solution. New York. 2020. Available online: https://www.xlstat.com (accessed on 1 March 2021).

64. Dunteman, G.H. Principal Components Analysis. In Quantitative Applications in the Social Sciences; Sage Publications: Newbury Park, CA, USA, 1989; Volume 69, pp. 96-101.

65. Matus, I.M.; Gonzales, G.; del Poso, A. Evaluation of phenotypic variation in a Chilean collection of garlic (Allium sativum L.) clones using multivariate analysis. Plant. Genet. Resour. Newslett. 1999, 117, 31-36.

66. Jain, A.K.; Flynn, P.; Ross, A.A. (Eds.) Handbook of Biometrics; Springer Science \& Business Media: Boston, MA, USA, 2007; p. 556. [CrossRef]

67. Friendly, M. Corrgrams: Exploratory Displays for Correlation Matrices; The American Statistician; Taylor \& Francis, Ltd.: Boca Raton, FL, USA, 2002; Volume 56, pp. 316-324. Available online: http://www.jstor.org/stable/3087354 (accessed on 12 April 2020). [CrossRef]

68. Rouse, J.W.; Hass, R.H.; Schell, J.A.; Deering, D.W.; Harlan, J.C. Monitoring the Vernal Advancement and Retrogradation (Green Wave Effect) of Natural Vegetation; Final Report, RSC 1978-4; Texas A\&M University: College Station, TX, USA, $1974 ;$ pp. 1-120.

69. Jurgens, C. The modified normalized difference vegetation index (mNDVI) a new index to determine frost damages in agriculture based on Landsat TM data. Int. J. Remote Sens. 1997, 18, 3583-3594. [CrossRef]

70. Roujean, J.-L.; Breon, F.-M. Estimating PAR absorbed by vegetation from bidirectional reflectance measurements. Remote Sens. Environ. 1995, 51, 375-384. [CrossRef]

71. Kim, M.S. The Use of Narrow Spectral Bands for Improving Remote Sensing Estimations of Fractionally Absorbed Photosynthetically Active Radiation. Doctoral Dissertation. 1994. Available online: http://hdl.handle.net/1903/24796 (accessed on 1 March 2021).

72. Daughtry, C. Estimating Corn Leaf Chlorophyll Concentration from Leaf and Canopy Reflectance. Remote Sens. Environ. 2000, 74, 229-239. [CrossRef]

73. Haboudane, D.; Miller, J.R.; Tremblay, N.; Zarco-Tejada, P.J.; Dextraze, L. Integrated narrow-band vegetation indices for prediction of crop chlorophyll content for application to precision agriculture. Remote Sens. Environ. 2002, 81, 416-426. [CrossRef]

74. Merzlyak, M.N.; Gitelson, A.A.; Chivkunova, O.B.; Rakitin, V.Y. Non-destructive optical detection of pigment changes during leaf senescence and fruit ripening. Physiol. Plant. 1999, 106, 135-141. [CrossRef]

75. Gamon, J.A.; Serrano, L.; Surfus, J.S. The photochemical reflectance index: An optical indicator of photosynthetic radiation use efficiency across species, functional types, and nutrient levels. Oecologia 1997, 112, 492-501. [CrossRef]

76. Peñuelas, J.; Baret, F.; Filella, I. Semi-empirical indices to assess carotenoids/chlorophyll a ratio from leaf spectral reflectance. Photosynthetica 1995, 31, 221-230.

77. Vogelmann, J.E.; Rock, B.N.; Moss, D.M. Red edge spectral measurements from sugar maple leaves. Int. J. Remote Sens. 1993, 14, 1563-1575. [CrossRef]

78. Barnes, E.M.; Clarke, T.R.; Richards, S.E.; Colaizzi, P.D.; Haberland, J.; Kostrzewski, M.; Waller, P.; Choi, C.; Riley, E.; Thompson, T.; et al. Coincident detection of crop water stress, nitrogen status and canopy density using ground based multispectral data. In Proceedings of the Fifth International Conference on Precision Agriculture, Bloomington, MN, USA, 16-19 July 2000; Volume 1619 , p. 15.

79. Merton, R.N. Monitoring community hysteresis using spectral shift analysis and the red-edge vegetation stress index. In Proceedings of the Seventh Annual JPL Airborne Earth Science Workshop, Pasadena, CA, USA, 12-16 January 1998 ; pp. 12-16.

80. Wang, L.; Qu, J.J. NMDI: A normalized multi-band drought index for monitoring soil and vegetation moisture with satellite remote sensing. Geophys. Res. Lett. 2007, 34. [CrossRef]

81. Babar, M.A.; Reynolds, M.P.; van Ginkel, M.; Klatt, A.R.; Raun, W.R.; Stone, M.L. Spectral Reflectance to Estimate Genetic Variation for In-Season Biomass, Leaf Chlorophyll, and Canopy Temperature in Wheat. Crop Sci. 2006, 46, 1046. [CrossRef]

82. Raun, W.R.; Johnson, G.V. Improving Nitrogen Use Efficiency for Cereal Production. J. Agron. 1999, 91, 357. [CrossRef]

83. Plett, D.C.; Ranathunge, K.; Melino, V.J.; Kuya, N.; Uga, Y.; Kronzucker, H.J. The intersection of nitrogen nutrition and water use in plants: New paths toward improved crop productivity. J. Exp. Bot. 2020, 71, 4452-4468. [CrossRef]

84. Setter, T.L.; Flannigan, B.A.; Melkonian, J. Loss of Kernel Set Due to Water Deficit and Shade in Maize. Crop Sci. 2001, 41, 1530. [CrossRef]

85. Gustin, J.L.; Boehlein, S.K.; Shaw, J.R.; Junior, W.; Settles, A.M.; Webster, A.; Tracy, W.F.; Hannah, L.C. Ovary abortion is prevalent in diverse maize inbred lines and is under genetic control. Sci. Rep. 2018, 8. [CrossRef]

86. Song, L.; Jin, J.; He, J. Effects of Severe Water Stress on Maize Growth Processes in the Field. Sustainability 2019, $11,5086$. [CrossRef]

87. Kresovic, B.; Matovic, G.; Gregoric, E.; Djuricin, S.; Bodroza, D. Irrigation as a climate change impact mitigation measure: An agronomic and economic assessment of maize production in Serbia. Agric. Water Manag. 2014, 139, 7-16. [CrossRef]

88. Farré, I.; Faci, J.M. Comparative response of maize (Zea mays L.) and sorghum (Sorghum bicolor L. Moench) to deficit irrigation in a Mediterranean environment. Agric. Water Manag. 2006, 83, 135-143. [CrossRef]

89. Wang, Y.; Liu, F.; Andersen, M.N.; Jensen, C.R. Improved plant nitrogen nutrition contributes to higher water use efficiency in tomatoes under alternate partial root-zone irrigation. Funct. Plant Biol. 2010, 37, 175. [CrossRef]

90. Hammad, H.M.; Farhad, W.; Abbas, F.; Fahad, S.; Saeed, S.; Nasim, W.; Bakhat, H.F. Maize plant nitrogen uptake dynamics at limited irrigation water and nitrogen. Environ. Sci. Pollut. Res. 2016, 24, 2549-2557. [CrossRef] 
91. Delegido, J.; Verrelst, J.; Meza, C.M.; Rivera, J.P.; Alonso, L.; Moreno, J. A red-edge spectral index for remote sensing estimation of green LAI over agroecosystems. Eur. J. Agron. 2013, 46, 42-52. [CrossRef]

92. Clevers, J.G.P.W.; De Jong, S.M.; Epema, G.F.; Van Der Meer, F.D.; Bakker, W.H.; Skidmore, A.K.; Scholte, K.H. Derivation of the red edge index using the MERIS standard band setting. Int. J. Remote Sens. 2002, 23, 3169-3184. [CrossRef]

93. Ballester, C.; Brinkhoff, J.; Quayle, W.C.; Hornbuckle, J. Monitoring the Effects of Water Stress in Cotton Using the Green Red Vegetation Index and Red Edge Ratio. Remote Sens. 2019, 11, 873. [CrossRef]

94. Zhao, D.; Reddy, K.R.; Kakani, V.G.; Reddy, V.R. Nitrogen deficiency effects on plant growth, leaf photosynthesis, and hyperspectral reflectance properties of sorghum. Eur. J. Agron. 2005, 22, 391-403. [CrossRef]

95. Gazala, I.F.S.; Sahoo, R.N.; Pandey, R.; Mandal, B.; Gupta, V.K.; Singh, R.; Sinha, P. Spectral reflectance pattern in soybean for assessing yellow mosaic disease. Indian J. Virol. 2013, 24, 242-249. [CrossRef]

96. Wang, F.-M.; Huang, J.-F.; Wang, X.-Z. Identification of Optimal Hyperspectral Bands for Estimation of Rice Biophysical Parameters. J. Integr. Plant Biol. 2008, 50, 291-299. [CrossRef]

97. Abbasi, M.; Verrelst, J.; Mirzaei, M.; Marofi, S.; Riyahi Bakhtiari, H.R. Optimal Spectral Wavelengths for Discriminating Orchard Species Using Multivariate Statistical Techniques. Remote Sens. 2019, 12, 63. [CrossRef]

98. Grossman, Y.L.; Ustin, S.L.; Jacquemoud, S.; Sanderson, E.W.; Schmuck, G.; Verdebout, J. Critique of stepwise multiple linear regression for the extraction of leaf biochemistry information from leaf reflectance data. Remote Sens. Environ. 1996, 56, 182-193. [CrossRef]

99. Strachan, I.B.; Pattey, E.; Boisvert, J.B. Impact of nitrogen and environmental conditions on corn as detected by hyperspectral reflectance. Remote Sens. Environ. 2002, 80, 213-224. [CrossRef]

100. Gupta, V.; Reinke, K.; Jones, S. Changes in the spectral features of fuel layers of an Australian dry sclerophyll forest in response to prescribed burning. Int. J. Wildland Fire 2013, 22, 862-868. [CrossRef]

101. Putra, B.T.W.; Soni, P. Evaluating NIR-Red and NIR-Red edge external filters with digital cameras for assessing vegetation indices under different illumination. Infrared Phys. Technol. 2017, 81, 148-156. [CrossRef]

102. Imran, A.B.; Khan, K.; Ali, N.; Ahmad, N.; Ali, A.; Shah, K. Narrow band based and broadband derived vegetation indices using Sentinel-2 Imagery to estimate vegetation biomass. Glob. J. Environ. Sci. Manag. 2020, 6, 97-108.

103. Jiang, Z.; Huete, A.R.; Chen, J.; Chen, Y.; Li, J.; Yan, G.; Zhang, X. Analysis of NDVI and scaled difference vegetation index retrievals of vegetation fraction. Remote Sens. Environ. 2006, 101, 366-378. [CrossRef]

104. Ranjan, R.; Chopra, U.K.; Sahoo, R.N.; Singh, A.K.; Pradhan, S. Assessment of plant nitrogen stress in wheat (Triticum aestivum L.) through hyperspectral indices. Int. J. Remote Sens. 2012, 33, 6342-6360. [CrossRef]

105. Bolton, D.K.; Friedl, M.A. Forecasting crop yield using remotely sensed vegetation indices and crop phenology metrics. Agric. For. Meteorol. 2013, 173, 74-84. [CrossRef]

106. Ghosh, P.; Mandal, D.; Bhattacharya, A.; Nanda, M.K.; Bera, S. Assessing Crop Monitoring Potential of Sentinel-2 in a SpatioTemporal Scale. Int. Arch. Photogramm. Remote Sens. Spat. Inf. Sci. 2018, XLII-5, 227-231. [CrossRef]

107. Peng, Y.; Gitelson, A.A.; Sakamoto, T. Remote estimation of gross primary productivity in crops using MODIS $250 \mathrm{~m}$ data. Remote Sens. Environ. 2013, 128, 186-196. [CrossRef]

108. Clevers, J.G.P.W.; Gitelson, A.A. Remote estimation of crop and grass chlorophyll and nitrogen content using red-edge bands on Sentinel-2 and -3. Int. J. Appl. Earth Obs. Geoinf. 2013, 23, 344-351. [CrossRef]

109. Schlemmer, M.; Gitelson, A.; Schepers, J.; Ferguson, R.; Peng, Y.; Shanahan, J.; Rundquist, D. Remote estimation of nitrogen and chlorophyll contents in maize at leaf and canopy levels. Int. J. Appl. Earth Obs. Geoinf. 2013, 25, 47-54. [CrossRef]

110. Rock, B.N.; Hoshizaki, T.; Miller, J.R. Comparison of in situ and airborne spectral measurements of the blue shift associated with forest decline. Remote Sens. Environ. 1988, 24, 109-127. [CrossRef]

111. Ramachandiran, K.; Pazhanivelan, S. Determination of nitrogen and water stress with hyper spectral reflectance on maize using classification tree (CT) analysis. J. Agrometeorol. 2015, 17, 213.

112. Zarco-Tejada, P.J.; Ustin, S.L.; Whiting, M.L. Temporal and Spatial Relationships between Within-Field Yield Variability in Cotton and High-Spatial Hyperspectral Remote Sensing Imagery. Agron. J. 2005, 97, 641. [CrossRef]

113. Le Maire, G.; François, C.; Dufrêne, E. Towards universal broad leaf chlorophyll indices using PROSPECT simulated database and hyperspectral reflectance measurements. Remote Sens. Environ. 2004, 89, 1-28. [CrossRef]

114. Ju, W.; Gao, P.; Wang, J.; Zhou, Y.; Zhang, X. Combining an ecological model with remote sensing and GIS techniques to monitor soil water content of croplands with a monsoon climate. Agric. Water Manag. 2010, 97, 1221-1231. [CrossRef]

115. Raper, T.B.; Varco, J.J. Canopy-scale wavelength and vegetative index sensitivities to cotton growth parameters and nitrogen status. Precis. Agric. 2014, 16, 62-76. [CrossRef]

116. Li, F.; Miao, Y.; Feng, G.; Yuan, F.; Yue, S.; Gao, X.; Liu, Y.; Liu, B.; Ustin, S.L.; Chen, X. Improving estimation of summer maize nitrogen status with red edge-based spectral vegetation indices. Field Crops Res. 2014, 157, 111-123. [CrossRef]

117. Wang, Z.; Wang, T.; Darvishzadeh, R.; Skidmore, A.K.; Jones, S.; Suarez, L.; Woodgate, W.; Heiden, U.; Heurich, M.; Hearne, J. Vegetation Indices for Mapping Canopy Foliar Nitrogen in a Mixed Temperate Forest. Remote Sens. 2016, 8, 491. [CrossRef]

118. Ihuoma, S.O.; Madramootoo, C.A. Crop reflectance indices for mapping water stress in greenhouse grown bell pepper. Agric. Water Manag. 2019, 219, 49-58. [CrossRef]

119. Caturegli, L.; Matteoli, S.; Gaetani, M.; Grossi, N.; Magni, S.; Minelli, A.; Corsini, G.; Remorini, D.; Volterrani, M. Effects of water stress on spectral reflectance of bermudagrass. Sci. Rep. 2020, 10, 1-12. 
120. Carter, G.A. Primary and secondary effects of water content on the spectral reflectance of leaves. Am. J. Bot. 1991, 78, 919-924. [CrossRef]

121. Sims, D.A.; Gamon, J.A. Estimation of vegetation water content and photosynthetic tissue area from spectral reflectance: A comparison of indices based on liquid water and chlorophyll absorption features. Remote Sens. Environ. 2003, 84, 526-537. [CrossRef]

122. Ihuoma, S.O.; Madramootoo, C.A. Recent advances in crop water stress detection. Comput. Electron. Agric. 2017, 141, $267-275$. [CrossRef]

123. Danson, F.M.; Steven, M.D.; Malthus, T.J.; Clark, J.A. High-spectral resolution data for determining leaf water content. Int. J. Remote Sens. 1992, 13, 461-470. [CrossRef]

124. Peñuelas, J.; Filella, I.; Biel, C.; Serrano, L.; Save, R. The reflectance at the $950-970 \mathrm{~nm}$ region as an indicator of plant water status. Int. J. Remote Sens. 1993, 14, 1887-1905. [CrossRef]

125. Govind, A.M.B.; Kumari, J.; Govind, A. Efficacy of different indices derived from spectral reflectance of wheat for nitrogen stress detection. J. Plant Interact. 2005, 1, 93-105. [CrossRef] 